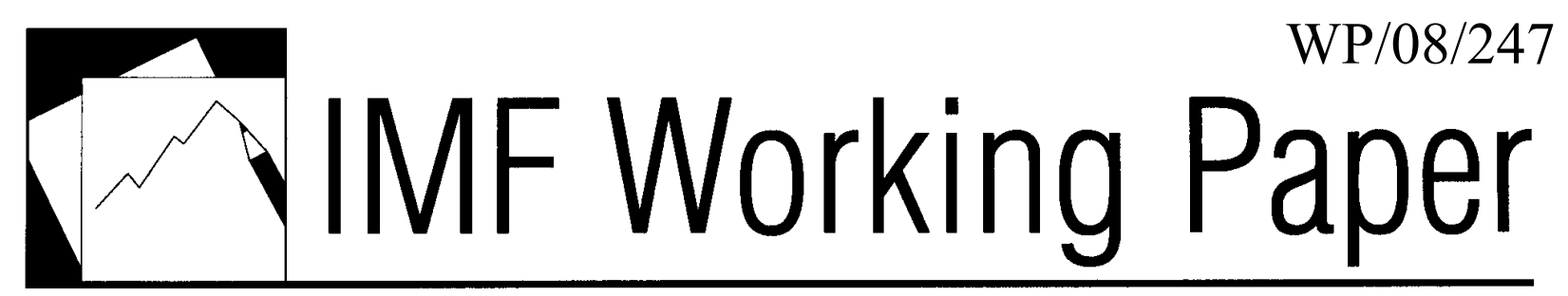

\title{
Interest Rate Elasticity of Residential Housing Prices
}

Plamen Iossifov, Martin Čihák, and Amar Shanghavi 



\title{
IMF Working Paper
}

\author{
African Department \\ Interest Rate Elasticity of Residential Housing Prices \\ Prepared by Plamen Iossifov, Martin Čihák, and Amar Shanghavi ${ }^{1}$ \\ Authorized for distribution by Cyrille Briançon
}

October 2008

\begin{abstract}

\section{This Working Paper should not be reported as representing the views of the IMF.}

The views expressed in this Working Paper are those of the authors and do not necessarily represent those of the IMF or IMF policy. Working Papers describe research in progress by the authors and are published to elicit comments and to further debate.
\end{abstract}

We examine the interest rate elasticity of housing prices, advancing the empirical literature in two directions. First, we take a commonly used cross-country panel dataset and evaluate the housing price equation using a consistent estimator in the presence of endogenous explanatory variables and a lagged dependent variable. Second, we carry-out a novel analysis of determinants of residential housing prices in a cross-section of countries. Our results show that the short-term interest rate, and hence monetary policy, has a sizable impact on residential housing prices.

JEL Classification Numbers: R21, R31

Keywords: Housing prices

Authors' E-Mail Addresses: piossifov@imf.org; mcihak@imf.org

\footnotetext{
${ }^{1}$ Amar Shanghavi, who worked on the paper while at the IMF, is presently a graduate student at the London School of Economics. We thank Angana Banerji, Cyrille Briançon, Roberto Cardarelli, Jörg Decressin, Marco Espinosa, Daniel Hardy, Paul Hilbers, Alexander Hoffmaister, and Emil Stavrev for useful comments. The usual disclaimers apply.
} 
I. Introduction

Contents

II. Literature Overview

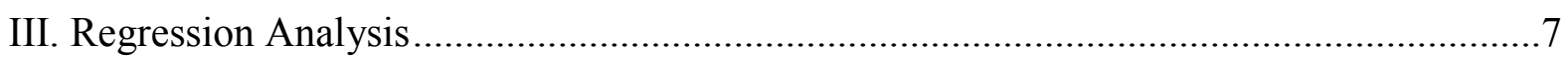

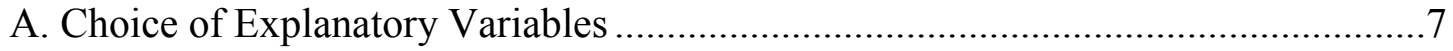

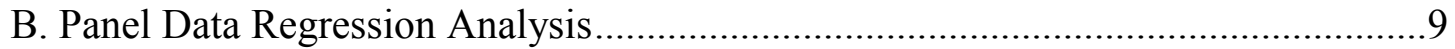

C. Cross-Section Regression Analysis......................................................................13

D. Preferred Estimate of the Interest Rate Elasticity of Housing Prices .....................15

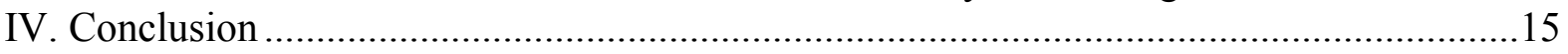

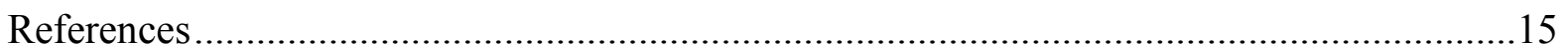

Appendices

I. Survey of Studies of Determinants of Housing Prices ................................................20

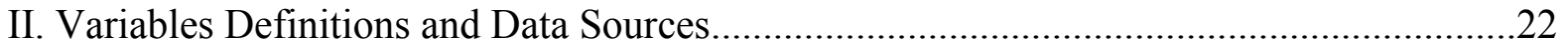

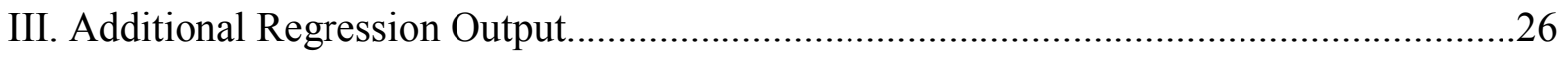

Tables

1. 3SLS Estimates of the Residential Housing Price Equation in First-Differences ...............12

2. OLS Estimates of the Housing Price Equation Using Cross-Country Data .......................14

Appendix Tables

1. Variables Definitions and Data Sources .....................................................................22

2. Within (Fixed Effects) Estimates of the Residential Housing Price Equation ...................28

3. OLS and Within Estimates of Unrestricted Residential Housing Price Equation ..............29

4. IV and GMM Panel Data Estimates of the Residential Housing Price Equation in First-

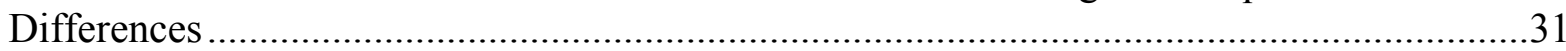

5. OLS Estimates of the Effect of Fundamentals on Residential Housing Prices in Cross-

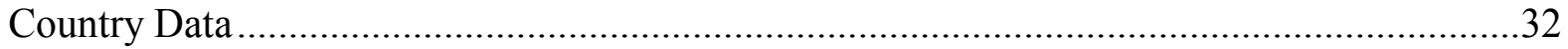

Appendix Figures

1. Real Residential Housing Price Indices, 1980-2007 .................................................24

2. Scatter Plots of Residential Housing Prices on Fundamental Determinants .....................25 


\section{INTRODUCTION}

Despite a recent proliferation of empirical studies on determinants of residential housing prices, there is still no consensus on key characteristics of the aggregate residential housing price equation. In particular, existing studies provide conflicting evidence on the elasticity of residential housing prices with respect to the short-term interest rate. Given that the latter is one of the few policy instruments that influence housing prices, knowledge of the magnitude of its impact on the housing market is important for policy makers. This question has recently garnered increased attention given the cooling-off of a number of major real estate markets. In this study, we attempt to provide an answer using two different cross-country datasets and an arsenal of econometric techniques. In what follows, Section II reviews the theoretical and empirical literature on determinants of residential housing prices, and identifies the main findings and gaps in the literature, as well as our contributions to it, Section III presents the regression analysis, and Section IV draws conclusions.

\section{Literature OVERVIEW}

\section{Theoretical models}

Residential housing is a durable good producing service streams that satisfy the basic human need for shelter while simultaneously serving as a store of purchasing power (Zhu, 2003; Barker, 2005). Households have the choice of buying the whole asset (own real estate) or just the service streams it yields (rent). As a result, each real estate property commands two prices_one for the stock of the asset and another for the flow of services it provides over a given period.

Theoretical models of the demand for residential housing emphasize the different margins of substitution involved in the household's optimization problem. In equilibrium (Poterba, 1984; Iacoviello, 2005) the household should be indifferent between owning and renting and between consuming the stream of services from an extra unit of housing, either bought or rented, and an extra unit of the consumption good. In addition, at an optimum, residential housing should have the same marginal rate of return, in terms of contribution to the household's future utility, as the other assets in the household portfolio. This rate of return should equal the marginal rate of substitution between consumption today and in the future. In the presence of uncertainty, considerations about the relative riskiness of owning versus renting, and of real estate versus other assets enter the household optimization problem (Flavin and Yamashita, 2002; Sinai and Souleles, 2005).

The demand for residential housing at the level of individual households is negatively related to the user cost of residential housing and positively related to life-cycle wealth, which includes "initial assets, current income and discounted expected income" (Muellbauer and Murphy, 1997, p. 1709). In deciding on how much housing to own, homeowners choose the amount that equalizes the marginal utility of an additional unit of housing to its marginal user cost. The user cost is the difference between the monetary costs and benefits of home 
ownership over a period of time. It equals "the sum of after-tax depreciation, repair costs, property taxes, mortgage interest payments, and the opportunity cost of housing equity, minus the capital gain...on the housing structure" (Poterba, 1984, p. 732).

Most real estate purchases are financed by borrowing, using the value of the property as collateral, or intergenerational transfers. The need for external financing of real estate purchases stems from the fact that the average home price is a multiple of average annual household disposable income and the first-time purchase of a house typically occurs early in the household life-cycle. The importance of external financing in home-ownership decisions makes its characteristics and their changes over time major determinants of the demand for residential housing.

Credit rationing makes the level of initial assets, current income and the mortgage rate relatively more important in determining demand for residential housing than expected future income streams and capital gains. In almost all developed countries there are limits on the proportion of the sale price of a property that can be financed with a mortgage (Blöndal, and Girouard, 2001). Prospective homeowners fund the remainder of the sale price (in the form of a downpayment) from their current net equity. In addition, mortgage lenders typically adhere to limits of the ratios between the overall size of the mortgage and/or the size of mortgage installments and the homeowner's disposable income.

Preferential tax treatment of capital gains from home ownership and tax deductibility of mortgage interest payments are important factors underlying demand for residential housing (Poterba, 1984; ECB, 2003). In most countries tax policies promote homeownership on the premise that it gives rise to positive externalities, such as more active civic involvement and more stable communities with common interests (Leung, 2004).

On the supply side, under perfect competition, the volume of housing construction is determined by the real prices of inputs. In equilibrium, the economic cost of producing an extra unit of housing should equal the price at which it is sold. Therefore, if there are no market imperfections the price of residential housing is fully determined by real construction costs and the real price of land (Hilbers, Lei, and Zacho, 2001; Himmelberg, Mayer, and Sinai, 2005). ${ }^{2}$

The existence of supply-side rigidities and other market imperfections make real estate prices primarily demand-driven in the short run (more so in large urban areas). In the 20 years through 2005, residential housing prices in developed countries grew, on average, almost

\footnotetext{
${ }^{2}$ If competition in housing construction is less than perfect, residential housing prices depend also on the degree of market power enjoyed by the construction companies.
} 
twice as fast as the deflator for gross fixed capital formation in housing construction. ${ }^{3}$ Zhu (2003, p. 10) succinctly describes the main characteristics of real estate markets:

The supply of property is intensively local; delivery of the new stock can take quite a long time owing to the length of the planning and construction phases; rents can be very sticky because of the use of long-term rental contracts; market prices lack transparency and most transactions occur through bilateral negotiations; the liquidity of the market is constrained because of the existence of high transaction costs; borrowers rely heavily on external finance; real estate is widely used as collateral; and short sales are usually not possible.

Zoning regulations, often designed to support property values for current homeowners, and the scarcity of land further limit the supply of residential housing (Case, 2000; Himmelberg, Mayer, and Sinai, 2005). Supply-demand imbalances in the market for real estate manifest themselves in the price of land, on which dwellings are built. Persistent excess demand pressures result in land prices growing faster than the price of structures (Himmelberg, Mayer, and Sinai, 2005).

At the aggregate level, in the face of inelastic supply, the relation between residential housing prices and other economic variables in the short run is given by the inverted aggregate demand function for residential housing. Credit constraints are binding for some but not for other households. Therefore, the average price of residential housing depends on a mixture of factors that influence the home-ownership decisions of these two segments of the population.

Real estate market imperfections open the possibility for housing price bubbles ${ }^{4}$ because the price of owner-occupied housing depends in part on its expected future path. For households not constrained by credit rationing, the expected capital gains on owner-occupied housing lower the user cost of home ownership, encouraging those who already own homes to trade up to bigger houses and creating incentives that bring new entrants in the market. The resulting demand pressures will have an impact on the current price of residential housing, making it prone to deviate from the value implied by fundamentals (Hilbers, Lei, and Zacho, 2001).

\section{Empirical literature}

In recent years, a growing body of empirical literature has sought to establish the main determinants of residential housing prices. The accumulated evidence reviewed in Appendix I gives credence to the theoretical findings that the fundamental determinants of residential housing prices are aggregate household income and wealth (Muellbauer and Murphy, 1997;

\footnotetext{
${ }^{3}$ Authors' estimates based on data from Australian Bureau of Statistics (2005), Bureau of Economic Analysis (2005), Eurostat (2005), and Bank for International Settlements (2005).

${ }^{4}$ Stiglitz (1990) defines asset bubbles as arising when “...the reason that the price is high today is only because investors believe that the selling price is high tomorrow — when 'fundamental' factors do not seem to justify such a price— then a bubble exists."
} 
Almeida, Campbello, and Liu, 2006), the rate of unemployment, short- and long-term interest rates (Barker, 2005), inflation, returns on other assets, availability and terms of mortgage financing (Davis and Zhu, 2004; Annett, 2005; Almeida, Campbello, and Liu, 2006), tax incentives, and demographic factors (Egebo and Lienert, 1988; Hilbers, Lei, and Zacho, 2001).

These studies, however, do not provide clear guidance on the magnitude of the elasticity of residential housing prices with respect to short-term interest rates. Reported elasticities vary widely-roughly from zero to minus 8 (Appendix I). In reviewing the studies, we have identified two potential causes of the wide variance in estimates: the use of unsuitable estimation techniques; and differences in the average estimates derived from single-country datasets and cross-country panel datasets, likely stemming from issues of comparability of housing price data between countries. In particular, panel data studies report very low elasticities, typically smaller (in absolute value) than one, whereas single country study estimates are typically in the range of minus 3 to minus 8 .

A common weakness of existing studies on cross-country panel data is that they use econometric techniques unsuited to the data—pooled and within-group (fixed-effects) OLS in the presence of residual autocorrelation, and Arellano-Bond dynamic-panel GMM estimators applied on datasets with small cross-sectional unit dimension (Appendix I). More importantly, cross-country panel data studies use residential property prices expressed as country-specific indices, whose bases are not comparable across countries. ${ }^{5}$ Such data are better suited for analyzing the contributions of changes in the growth rates of explanatory variables to the rate of growth of housing prices than level elasticities, and can not be used to estimate equilibrium relationship between the dependent and explanatory variables in levels. Single-country studies do not have this problem, but it is difficult to draw conclusions that are valid for a set of countries, based on evidence from just one.

In this study, we advance the empirical literature in two directions. First, we take a commonly used cross-country panel dataset and estimate the residential housing price equation using an estimator that is consistent in the presence of endogenous explanatory variables and a lagged dependent variable - 3SLS with country-specific intercepts and crossequation restrictions on the other coefficients to make them equal across countries. The rationale for doing this is to see whether better-suited econometric techniques can resolve the above-mentioned inconsistency between panel-data and single-country estimates of the interest rate elasticity of residential housing prices. Second, we carry-out a novel analysis of determinants of residential housing prices in a cross-section of countries with the objective of gathering further evidence on the magnitude of the interest rate elasticity of residential housing prices.

\footnotetext{
${ }^{5}$ In the base year, housing prices expressed in comparable units (e.g., US\$) range widely across countries, whereas when expressed in index values they are the same (i.e., 100).
} 


\section{REGRESSION ANALYSIS}

We start our analysis with a commonly analyzed set of 20 advanced countries, for which quarterly data on an index of residential property prices are available over a long period of time (Appendix Figure 1). ${ }^{6}$ We then complement and contrast our findings with an analysis of cross-section data on residential property prices in US dollars per square meter in 2005-06 for 89 countries, as published by the Global Property Guide (www.globalpropertyguide.com) in mid-2007 (Appendix Figure 2). ${ }^{7}$ For many countries in the second dataset, the published data are compiled by in-house research by the Global Property Guide and are not official. This raises legitimate concerns about the reliability of the data, with which we had to contend, because this is the only source of such data that we are aware of. Checks for property markets with which we are familiar gave us a certain degree of assurance about the quality of the data.

\section{A. Choice of Explanatory Variables}

The choice of explanatory variables reflects the consensus in the reviewed literature that in the short run housing prices $^{8}$ are primarily determined by fundamentals affecting aggregate demand (Poterba, 1984; Ahearne and others, 2005; Annett, 2005). ${ }^{9}$ Leveraging published theoretical and empirical studies (Section II and Appendix I), we consider the following explanatory variables (data sources are described in Appendix II; the expected sign of regression coefficients is in square brackets):

\footnotetext{
${ }^{6}$ Our starting sample covers Australia, Austria, Belgium, Canada, Denmark, Finland, France, Germany, Ireland, Italy, Japan, Netherlands, New Zealand, Norway, Portugal, Spain, Sweden, Switzerland, United Kingdom, and the United States. The time span is from 1980 to 2007, but for many countries in the sample data are available only for shorter periods, generally since 1988. The sample is determined by the coverage of national data sources detailed in Appendix II and the residential property price database maintained by the Bank for International Settlements (BIS, 2005). Like most other authors, we do not perform formal "poolability" tests of the countries in the sample, relying instead on their common socioeconomic characteristics as OECD countries.

${ }^{7}$ Data was available for 118 countries, but our starting sample consisted of 93 countries because of lack of data on explanatory variables. In the course of the exploratory stage of the regression analysis, we further dropped Ecuador, India, The Gambia and Paraguay based on outlier analysis.

${ }^{8}$ Throughout the paper, the term housing is used in reference to residential housing (i.e., not commercial and office buildings).

${ }^{9}$ The $25+$ years span of the cross-country panel dataset certainly stretches the definition of short-run. However, data on supply-side fundamentals, as well as the characteristics of the rental markets, does not exist at the frequency, time span, and country coverage of our datasets, which is why we do not include such variables in the analysis. This is a shared weakness with most empirical studies on the subject.
} 
- $[+]$ Scale variable proxying life-cycle wealth $-\log$ of real per capita purchasing power parity (PPP) gross domestic product $\left(n \_p c r g d p p p\right){ }^{10}$ in panel data regressions and $\log$ of per capita GDP in US dollars (ln_pcgdpusd) in cross-section regressions.

- $\quad[-]$ Short-term interest rate (srate in nominal terms and $r_{-}$srate - in real)-proxy for the opportunity cost of investments in owner-occupied housing. Higher opportunity costs are likely to decrease demand for owner-occupied housing, and thus housing prices.

- $\quad[-]$ Slope of the yield curve (slpyc) - the spread between long- and short-term rates gives information about the direction of movement of future short-term interest rates and hence on potential capital gains or losses on owner-occupied housing (Himmelberg, Mayer, and Sinai, 2005). Its inclusion is also a convenient way of testing which interest rate (the long- or the short-term one) is more important in the housing market. The long-term interest rate is a proxy for the cost of mortgage financing.

- $\quad[+]$ Rate of inflation (infl) - proxy for the repayment burden of mortgage debt (Poterba, 1984). Mortgage debt is typically extended in nominal amounts, which are not automatically indexed to changes in inflation. Higher inflation is therefore likely to be associated with higher housing prices, because it makes mortgage debt more affordable.

- $\quad[-]$ Unemployment rate (unemplr) - provides information about the distribution of income across households (Blinder and Esaki, 1978). High unemployment diminishes the pool of home buyers.

- $\left.\quad{ }^{+}\right]$Measures of financial deepening $-\log$ of real broad money M2 $\left(l n_{-} r \_m 2\right)$ in panel data regressions, and domestic credit to the private sector as a ratio to GDP ( $c r d \_g d p$ ) in cross-section regressions. Deeper financial markets extend and improve public access to financial services, thus stimulating housing demand.

- $[+]$ Demographic variables approximating the number of potential buyers in the market - share of active population in total population (shpopa) in panel data regressions ${ }^{11}$ and share of urban population (shpopurb) in cross-section regressions. A higher share is likely to be associated with higher prices.

\footnotetext{
${ }^{10}$ In the regression analysis, all variables in levels are entered in real terms to ensure cross-country comparability by removing the scale effect due to diminishing purchasing power of the domestic currency.

${ }^{11}$ We have also experimented with the growth rate of total population, as an alternative variable to capture demographic differences. We present only regressions with shpopa, because it turned out to be statistically significant in many more regression specifications than the growth rate of total population.
} 
- $\quad[+]$ Primary government balance as a ratio to GDP (govbal) - the crowding-out effect of the financing of budget deficits, by adversely affecting the availability of mortgage financing, depresses housing prices. Housing prices and the government budget balance may also be positively correlated because higher housing prices increase real estate tax revenues and because they are both pro-cyclical. The empirical literature generally overlooks these links, but papers that include the fiscal sector tend to find that housing prices co-move with budget balances (e.g., Ahearne and others, 2005), even after controlling for macroeconomic factors, such as income and interest rates.

- $\quad$ [-] Current account balance as a ratio to GDP (curracc) - the wealth effect of rising housing prices leads to higher consumption and lower savings, which has a negative impact on the economy's savings-investment balance and hence the current account. Whereas this points to reverse causality, in some countries foreign buyers are important players in the housing market. In these countries, sustained current account deficits are often made possible by capital inflows associated with housing purchases by foreigners. As with the primary government balance, the empirical literature generally overlooks the current account as an explanatory variable for housing prices.

\section{B. Panel Data Regression Analysis}

The housing price equation is estimated in semi-loglinear form. The dependent variable is the $\log$ of the real residential property price index (ln_r housprc) ${ }^{12}$ Appendix III summarizes the exploratory stage of the regression analysis, which shows that the residential housing price equation can be reasonably estimated in first-differences as a simple partial adjustment model with country-specific intercepts and main determinants the real per capita PPP GDP, the real broad money, the nominal short-term interest rate (in level), the rates of inflation and unemployment, and the ratio of the government balance to GDP (Appendix Table 2). As both the pooled OLS and the within-group estimators used in the exploratory stage of the regression analysis are inconsistent in the presence of a lagged dependent variable (Hsiao, 2003, p. 72-4), we next turn to more sophisticated econometric techniques.

One possibility is to use the popular Arellano-Bond dynamic-panel GMM estimators. However, these are only well defined when the time dimension of the sample is smaller than the cross-sectional unit dimension (Arellano, 2003, p. 90). In addition, to rely on the asymptotic properties of the estimators, the cross-sectional unit dimension must be very large. The estimators are asymptotically biased when the ratio of the time and cross-sectional unit dimensions tends to a nonzero constant (Arellano, 2003, p. 170). Finally, to avoid finite sample bias caused by overfitting the number of instruments used in the estimation procedure must be less than or equal to the number of cross-sectional units (Roodman, 2003). Because

\footnotetext{
${ }^{12}$ All variables in levels are entered in real terms to ensure cross-country comparability by removing the scale effect due to diminishing purchasing power of the domestic currency.
} 
all these conditions for consistency of the Arellano-Bond dynamic-panel GMM estimators are not met in the case of our dataset, it comes as no surprise that the estimation of Model 6 by the GMM-DIF, GMM-SYS, and Anderson and Hsiao instrumental variables (A-H IV) estimators breaks down (Appendix III, Appendix Table 4). The datasets used in all empirical studies of housing prices that employ Arellano-Bond dynamic-panel GMM estimators do not meet at least two of the three consistency conditions, raising questions about the validity of their findings.

An alternative approach, rarely used in practice due to implementation difficulties, is to estimate Model 6 by 2SLS or 3SLS with country-specific intercepts and cross-equation restrictions on the other coefficients to make them equal across countries. Both methods are consistent in the presence of endogenous explanatory variables and a lagged dependent variable (Greene, 1997, Chapter 16; Hayashi, 1992, p. 15; Arellano, 2003, p. 133). The 3SLS estimator is more efficient because it uses the additional information contained in the covariance structure of the errors in the different equations of the system.

In our implementation of these estimators, ${ }^{13}$ we first construct the housing price equation for each country in the sample, with time-indexed observations, and then form a system of simultaneous equations from the housing price equations for all countries in the sample. In the system we restrict the coefficients of all explanatory variables to being the same across countries except for country-specific intercepts. We treat all explanatory variables as endogenous. The efficiency gains of using 3SLS over 2SLS in estimating the system of country housing price equations are likely to be significant, given the high degree of comovement of residential housing prices across countries, which indicates the presence of global exogenous shocks or spillover effects (Appendix Figure 1).

The reg3 STATA procedure (StataCorp, 2005) drops missing observations across all equations rather than individually for each equation. Because of this, we drop three countries from the sample — Belgium, France, and Germany_-due to a large number of missing observations. ${ }^{14}$ Furthermore, the reg3 procedure applies the same set of instruments to all equations in the system. Given the structure of the system, the number of suitably lagged explanatory variables that can serve as potential instruments greatly exceeds the degrees of freedom of each equation in the system. In the case of Model 6, there are seven lagged explanatory variables for each of the 17 countries in the sample, for a total of 119 potential instruments, compared to 65 observations per country. Rather than choosing among what appear to be equally well suited instruments and exposing ourselves to criticism of cherrypicking our regression findings, we resort to well established statistical techniques for data

\footnotetext{
${ }^{13}$ In a user-defined STATA macro build around the reg3 STATA procedure.

${ }^{14}$ In the case of Germany, the data before and after the country's reunification is not comparable, so observations prior to 1991 are discarded. In the case of the other two countries, the missing observations are for the residential property price index.
} 
reduction. In particular, for each explanatory variable in Model 6, we take the variables capturing its realization in the sample countries and extract from the resulting dataset the first five principal components. ${ }^{15}$ The set of instruments, used on all equations in the system, is then obtained by taking the second lags of the first five principal components of the countryrealizations of all explanatory variables. For Model 6, which has seven explanatory variables, this approach gives us 35 instruments for use in all equations of the system. The instruments are lagged by two periods to ensure their exogeneity with respect to the system's error terms, which by construction equal the first-difference of the residuals of the regressions in levels.

Table 1 presents the 3SLS estimates of Model 6 and its subsequent refinements. ${ }^{16}$ The time dimension for each country is from 1990:4 to 2006:Q4.

The 3SLS estimates of Model 6 add to the accumulated evidence, from pooled and withingroup OLS estimates, in support of the theoretical predictions of interdependencies between real residential housing prices and their main determinants. All statistically significant coefficients reported in the first column of Table 1 have the same signs as when calculated by pooled and within-group OLS. The coefficients of the short-term interest rate and the quarterto-quarter growth rate of inflation and real broad money are statistically significant at the 99 percent level of confidence, with point estimates higher (in absolute values) than their withingroup OLS counterparts. The point estimates of the coefficients of the other explanatory variables are lower (in absolute values) than their within-group OLS counterparts, with the quarter-to-quarter growth rate of real per capita PPP GDP being statistically insignificant at the 90 percent level of confidence.

Model 6 contains a number of explanatory variables with low level of significance. We proceed to drop, in steps, those that are statistically insignificant at the 90 percent level of confidence (Model 7). Dropping real per capita PPP GDP makes the rate of unemployment statistically insignificant, so we drop it from Model 8.

Model 8 is our preferred regression specification of the residential housing price equation in first-differences. It fits the data well, with a median R-squared of the country residential housing price equations in first-differences of $0.33 .{ }^{17}$ Also, in the system of equations all but one first-order residual autocorrelations, statistically significant at the 95 percent level of confidence, are close in value to -0.5 . This serves as an informal test for the lack of firstorder serial correlation in excess of the theoretically predicted value of -0.5 (Arellano, 2003, p. 121). According to their 3SLS estimates in Model 8, the long-run elasticities of the

\footnotetext{
${ }^{15}$ The principal components are linear combinations of all variables in the dataset, the values of which capture best the variability of the original data. See the documentation of the PCA procedure in STATA for more information.

${ }^{16}$ We do not present the 2SLS estimates, which were qualitatively similar to the 3 SLS results.

${ }^{17}$ In other words, the model explains more than 33 percent of the variability of the dependent variable in half of the sample countries and less than 33 percent in the other half.
} 
quarter-on-quarter growth rate of real residential housing prices with respect to the explanatory variables are such that: ${ }^{18}$

- A 1 percentage point increase in the nominal short-term interest rates from one quarter to the next is associated with a 0.24 percentage point decline in the quarteron-quarter growth rate of real residential housing prices.

- A 1 percentage point increase in the quarter-on-quarter inflation is associated with a 0.31 percentage point decline in the quarter-on-quarter growth rate of real residential housing prices.

- A 1 percentage point increase in the ratio of the primary government balance to GDP from one quarter to the next is associated with a 0.8 percentage point increase in the quarter-on-quarter growth rate of real residential housing prices.

- $\quad$ A 1 percentage point increase in the quarter-on-quarter growth rate of real broad money is associated with a 0.14 percentage point increase in the quarter-on-quarter growth rate of real residential housing prices.

Table 1. 3SLS Estimates of the Residential Housing Price Equation in First-Differences

\begin{tabular}{lccc}
\hline & $(6)$ & $(7)$ & $(8)$ \\
\hline d1_In_r_housprc_1 & $0.432^{* *}$ & $0.460^{* *}$ & $0.453^{* *}$ \\
d1_In_pcrgdppp & $(0.034)$ & $(0.034)$ & $(0.037)$ \\
& -0.065 & & \\
srate ${ }^{1}$ & $(0.079)$ & & \\
& $-0.124^{* *}$ & $-0.117^{* *}$ & $-0.131^{* *}$ \\
d1_infl & $(0.018)$ & $(0.018)$ & $(0.018)$ \\
& $-0.152^{* *}$ & $-0.159^{* *}$ & $-0.173^{* *}$ \\
d1_unemplr & $(0.017)$ & $(0.017)$ & $(0.018)$ \\
& $-0.428^{*}$ & -0.317 & \\
d1_govbal & $(0.195)$ & $(0.198)$ & \\
& $0.228^{* *}$ & $0.242^{* *}$ & $0.385^{* *}$ \\
d1_In_r_m2 & $(0.073)$ & $(0.080)$ & $(0.086)$ \\
& $0.087^{* *}$ & $0.092^{* *}$ & $0.076^{*}$ \\
& $(0.029)$ & $(0.030)$ & $(0.032)$ \\
\hline Observations per country & 65 & 65 & 65 \\
Number of countries & 17 & 17 & 17 \\
Median R-squared & 0.32 & 0.34 & 0.33 \\
Significant first-order residual & & & \\
autocorrelation coefficients: & $-0.45^{* *}$ & $-0.46^{* *}$ & $-0.46^{* *}$ \\
& $-0.37^{*}$ & $-0.39^{*}$ & $-0.38^{*}$ \\
& $0.36^{*}$ & & $0.35^{*}$ \\
\hline
\end{tabular}

Notes:

Standard errors in parentheses.

+ significant at 10\%; * significant at $5 \%$; ${ }^{* *}$ significant at $1 \%$.

All variables in first-differences unless otherwise specified.

1 Untransformed variable.

Country-specific intercepts not shown.

\footnotetext{
${ }^{18}$ The long-run elasticities are obtained by dividing the 3SLS coefficient estimates, excluding that of the lagged dependent variable, by one minus the coefficient of the lagged dependent variable.
} 
In addition, the estimate of the coefficient of the lagged dependent variable (0.45) implies a reasonable speed of adjustment of the actual growth rate of real residential housing prices to the value consistent with fundamentals, with approximately 55 percent of any gap between the two being closed in each subsequent quarter. It also points to a significant degree of inertia in the quarter-on-quarter growth rates of real residential housing prices in the short run.

Our best estimate of the interest rate elasticity of housing prices, derived from the crosscountry panel dataset falls within the range of estimates reported by studies on similar datasets, i.e. it is relatively low. Therefore, the use of better-suited econometric techniques can not bridge the gap between the estimates of the interest rate elasticity of housing prices derived from single-country datasets and cross-country panel datasets.

\section{Cross-Section Regression Analysis}

We next address the question of whether the finding of a large interest-rate elasticity of housing prices (in excess of minus 3 ) in single-country datasets extends to a larger set of countries. To that end we perform what is to our best knowledge the first analysis of determinants of residential housing prices in a cross-section of countries. The housing price equation is estimated in semi-loglinear form. The dependent variable is the log of residential property prices in US dollars per square meter index (ln_housprcusd).

At the exploratory stage of the analysis we evaluate the different regression models by OLS with heteroskedasticity-adjusted standard errors (Appendix III). To avoid modeling explicitly the endogeneity of explanatory variables, we enter them as five-year averages on the premise that the impact of exogenous shocks on the dependent and explanatory variables would tend to cancel out over the span of a standard business cycle. Results show that the main determinants of residential housing prices are per capita GDP in US\$, the real short-term interest rate, and availability of credit as measured by the ratio of domestic credit to the private sector to GDP (Table 2, Model 19).

To control for time-invariant unobserved heterogeneity and measurement errors, we next sequentially add commonly used control variables, keeping those with statistically significant coefficients. We use regional dummies (with Europe being the omitted category) and indicators of quality of institutions compiled by the World Bank-business rank, ${ }^{19}$ corruption rank, ${ }^{20}$ and governance rank. ${ }^{21}$ Results show that only the regional dummies capture some of the unobserved heterogeneity in our dataset (Appendix Table 5).

\footnotetext{
${ }^{19}$ A lower rank is associated with greater efficiency in the business environment. Source: World Bank, Doing Business Database, www.doingbusiness.org/.

${ }^{20}$ A lower rank implies better control of corruption. Source: World Bank, Worldwide Governance Indicators, http://info.worldbank.org/governance/wgi/index.asp.
} 
Model 20 is our preferred regression specification of the residential housing price equation in levels. It fits the data well, with a R-squared of 0.63. According to their OLS estimates, the long-run elasticities of the quarter-on-quarter growth rate of real residential housing prices with respect to the explanatory variables are such that

- A 1 percentage point increase in the real short-term interest rate is associated with a 3.61 percentage points decline in residential housing prices.

- A 1 percentage point increase in per capita GDP in US\$ is associated with a 0.28 percentage point increase in residential housing prices.

- A 1 percentage point increase in the ratio of credit to private sector to GDP is associated with a 0.44 percentage point increase in residential housing prices.

- $\quad$ The coefficients of the regional dummy variables suggest that even after controlling for GDP per capita and credit market conditions, on average housing prices (in US\$ per square meter) in Africa are 63 percent lower than in Europe, and in Central and Latin America are 37 percent lower than in Europe. There are no statistically significant differences between average housing prices in Europe and North America and Asia and Pacific after controlling for macroeconomic fundamentals.

Table 2. OLS Estimates of the Housing Price Equation Using Cross-Country Data

\begin{tabular}{|c|c|c|}
\hline & (19) & (20) \\
\hline In_pcgdpusd & $\begin{array}{l}0.374 \text { ** } \\
(0.057)\end{array}$ & $\begin{array}{l}0.275^{* *} \\
(0.070)\end{array}$ \\
\hline r_srate & $\begin{array}{c}-4.324 \text { ** } \\
(1.566)\end{array}$ & $\begin{array}{c}-3.605 \text { * } \\
(1.803)\end{array}$ \\
\hline crd_gdp & $\begin{array}{l}0.398 \text { * } \\
(0.191)\end{array}$ & $\begin{array}{l}0.436 \\
(0.207)\end{array}$ * \\
\hline \multicolumn{3}{|l|}{ Regional dummy variables } \\
\hline Asia and Pacific & & $\begin{array}{r}-0.158 \\
(0.218)\end{array}$ \\
\hline North America & & $\begin{array}{r}-0.134 \\
(0.351)\end{array}$ \\
\hline Central and Latin America & & $\begin{array}{c}-0.369+ \\
(0.193)\end{array}$ \\
\hline Africa & & $\begin{array}{c}-0.627 \text { ** } \\
(0.195)\end{array}$ \\
\hline Intercept & $\begin{array}{l}4.392 \text { ** } \\
(0.415)\end{array}$ & $\begin{array}{l}5.425 \text { ** } \\
(0.578)\end{array}$ \\
\hline Number of countries & 89 & 89 \\
\hline Overall $\mathrm{R}^{2}$ & 0.59 & 0.63 \\
\hline
\end{tabular}

${ }^{21}$ Average rank on six governance indicators (control of corruption, rule of law, political stability and absence of violence, voice and accountability, regulatory quality and government effectiveness) with a lower rank indicating better governance. Source: World Bank, Worldwide Governance Indicators, http://info.worldbank.org/governance/wgi/index.asp. 


\section{Preferred Estimate of the Interest Rate Elasticity of Housing Prices}

Comparison of Model 8 (Table 1) and Model 20 (Table 2) shows that using residential housing prices expressed in comparable units across countries we obtain a much larger estimate of the interest-rate elasticity of housing prices, one that is within the range of estimates reported by single-country studies. Given the argued unsuitability of cross-country panel data on country-specific housing price indices to answer questions about the relationship between variables in levels, we pick the value (-3.6) from Model 20 as our best estimate of the interest-rate elasticity of housing prices. We are thus able to corroborate and extend to a much wider cross-section of countries the finding from existing single-country studies that the interest-rate elasticity of housing prices is greater than -3 .

\section{CONCLUSION}

Our best estimate of the elasticity of residential housing prices with respect to the short-run real interest rate is -3.6 , which falls within the range of estimates reported by single-country studies. We thus corroborate and extend to a much wider cross-section of countries the findings from existing single-country studies. We also show that better suited econometric techniques applied on a cross-country panel dataset can not bridge the gap between the estimates of the interest rate elasticity of housing prices derived from single-country datasets and cross-country panel datasets. We argue that this is due to inherent weaknesses of crosscountry panel data on country-specific housing price indices.

\section{REFERENCES}

Abelson, P., R. Joyeux, G. Milunovich and D. Chung, 2005, "Explaining House Prices in Australia: 1970-2003," Economic Record, Vol. 81, pp. S96-S103.

Australian Bureau of Statistics, 2005, Australian System of National Accounts, (Canberra: Australian Bureau of Statistics).

Ahearne, Alan, John Ammer, Brian Doyle, Linda Kole, and Robert Martin, 2005, "House Prices and Monetary Policy: A Cross-Country Study," International Finance Discussion Paper No. 841 (Washington: Board of Governors of the Federal Reserve System).

Almeida, Heitor, Murillo Campello, and Crocker Liu, 2006, “The Financial Accelerator: Evidence from International Housing Markets," Review of Finance, Vol. 10 (3), pp. 321-352.

Annett, Anthony, 2005, "House Prices and Monetary Policy in the Euro Area," in Euro Area Policies: Selected Issues, IMF Country Report No. 05/266, pp. 62-86 (Washington: International Monetary Fund). 
Arellano, Manuel, 2003, Panel Data Econometrics Advanced Texts in Econometrics, (Oxford, UK: Oxford University Press).

Arthur, Stephan, 2005, "Obtaining Real Estate Data: Criteria, Difficulties and Limitations," in Real Estate Indicators and Financial Stability, BIS Papers No. 21, pp. 63-69 (Basel: Bank for International Settlements).

Ayuso, J., J. Martinez, L. Maza and F. Restoy, 2003, "House Prices in Spain," Economic Bulletin, October (Madrid: Banco de Espana).

Barker, Kate, 2005, "The Housing Market and the Wider Economy," Bank of England Quarterly Bulletin, 45(1), Spring, pp. 108-16.

Bessone, A.-J., B. Heitz and J. Boissinot, 2005, “ Marché immobilier: voit-on une bulle?” Note de Conjoncture, mars, (Paris: INSEE).

Bureau of Economic Analysis (BEA), 2005, SNA and the NIPAs Dataset, www.bea.gov/bea/dn/sna/sna.htm (Washington: U.S. Department of Commerce, Bureau of Economic Analysis).

BIS, 2005, Residential Property Prices Database, unpublished (Basel: Bank for International Settlements).

—_, 2008, 78th Annual Report, www.bis.org/publ/arpdf/ar2008e.pdf (Basel: Bank for International Settlements).

Blinder, A. and Esaki, H., 1978, "Macroeconomic Activity and Income Distribution in the Postwar United States," Review of Economics and Statistics, Vol. 60, pp. 604-09.

Blöndal, S. and N. Girouard, 2001, "House Prices and Economic Activity," OECD Economics Department Working Papers, No. 279 (Paris and Washington: OECD).

Case, Karl, 2000, "Real Estate and the Macroeconomy," Brookings Papers of Economic Activity, Vol. 2, pp. 119-45.

Collyns, Charles and Senhadji Semlali, 2002, "Lending Booms, Real Estate Bubbles and The Asian Crisis," IMF Working Paper No. 02/20 (Washington: International Monetary Fund).

Doornik, Jurgen, Manuel Arellano, and Steven Bond, 2002, Panel Data Estimation Using $D P D$ for $O x$, www.doornik.com/download.html.

Drukker, D., 2003, “Testing for Serial Correlation in Linear Panel-Data Models," Stata Journal, Vol. 3 (2), pp. 168-177. 
ECB, 2003, Structural Factors in the EU Housing Markets (Frankfurt: European Central Bank).

Egebo, Thomas and Ian Lienert, 1988, "Modeling Housing Investment for Seven Major OECD Countries," OECD Economics Department Working Paper No. 63 (Paris and Washington: Organization for Economic Co-operation and Development).

EMF, 2007, Quarterly Review of European Mortgage Markets, August (Brussels: European Mortgage Federation).

Eurostat, 2005, Eurostat Database, http://epp.eurostat.ec.europa.eu.

Fitzpatrick, T. and K. McQuinn, 2004, "House Prices and Mortgage Credit: Empirical Evidence for Ireland," Research Technical Paper, No. 5/RT/04 (Dublin: Central Bank and Financial Services Authority of Ireland).

Flavin, Marjorie, and Takashi Yamashita, 2002, "Owner-Occupied Housing and the Composition of the Household Portfolio over the Life Cycle," American Economic Review, Vol. 92 (1), March, pp. 345-62.

Greene, William, 1997, Econometric Analysis, third ed. (Upper Saddle River, NJ: PrenticeHall).

Hayashi, Fumio, 1992, "On the Estimation of Panel-Data Models with Serial Correlation When Instruments Are Not Strictly Exogenous: Comment," Journal of Business \& Economic Statistics, Vol. 10 (1), Jan., pp. 15-17.

Hilbers, Paul, Qin Lei, and Lisbeth Zacho, 2001, "Real Estate Market Developments and Financial Sector Soundness,” IMF Working Paper No. 01/129 (Washington: International Monetary Fund).

Himmelberg, Charles, Christopher Mayer, and Todd Sinai, 2005, “Assessing High House Prices: Bubbles, Fundamentals and Misperceptions," NBER Working Paper, 11643 (Cambridge, MA: National Bureau Of Economic Research).

Hofman, D., 2005, "Kingdom of the Netherlands-Netherlands: Selected Issues", IMF Country Report, No. 05/225 (Washington: International Monetary Fund).

Hsiao, Cheng, 2003, Analysis of Panel Data, second ed. (Cambridge, UK: Cambridge University Press).

Hunt, B. and M. Badia, 2005, "United Kingdom: Selected Issues”, IMF Country Report, No. 05/81 (Washington: International Monetary Fund).

Iacoviello, Matteo, 2005, "House Prices, Borrowing Constraints, and Monetary Policy in the Business Cycle," American Economic Review, Vol. 95 (3), June, pp. 739-64. 
IMF, 2007, World Economic Outlook Database (Washington: International Monetary Fund).

— 2008, World Economic Outlook (April): Housing and the Business Cycle (Washington: International Monetary Fund).

Jacobsen, D. and B. Naug, 2005, "What Drives House Prices?", Norges Bank Economic Bulletin, Vol. 5, Q1 (Oslo: Norges Bank).

Leung, Charles, 2004, "Macroeconomics and Housing: A Review of the Literature," Journal of Housing Economics, Vol. 13 (4), December, pp. 249-67.

McCarthy, J. and R. Peach, 2004, “Are Home Prices the Next Bubble?”, Federal Reserve Bank of New York Economic Policy Review, December (New York: Federal Reserve Bank of New York).

Meen, G., 2002, "The Time-Series Behaviour of House Prices: A Transatlantic Divide", Journal of Housing Economics, Vol. 11, pp. 1-23.

Muellbauer, John and Anthony Murphy, 1997, "Booms and Busts in the UK Housing Market”, Economic Journal, Vol. 107 (445), November, pp. 1701-27.

Nagahata, T., Y. Saita, T. Sekine and T. Tachibana, 2004, "Equilibrium Land Prices of Japanese Prefectures: A Panel Cointegration Analysis", Bank of Japan Working Paper Series, No. 04-E-9.

Organization for Economic Co-operation and Development (OECD), 2004a, Chapter IV of OECD Economic Outlook, Vol. 75, June (Paris and Washington: OECD).

— 2004b, Economic Survey of the Netherlands (Paris and Washington: OECD).

$\longrightarrow$, 2004c, Economic Survey of Spain (Paris and Washington: OECD).

_ 2005, Economic Survey of Ireland (Paris and Washington: OECD).

—_, 2008, Economic Outlook: Annual and Quarterly Data, Vol. 2008 release 01 (Paris and Washington: OECD).

Oikarinen, E., 2005, "Is Housing Overvalued in the Helsinki Metropolitan Area", Keskusteluaiheita Discussion papers, No. 992 (Helsinki: The Research Institute of the Finnish Economy).

Poterba, James, 1984, "Tax Subsidies to Owner-Occupied Housing: An Asset-Market Approach," Quarterly Journal of Economics, Vol. 99 (4), November, pp. 729-752. 
Roodman, David, 2003, "Help for XTABOND2: Stata Module to Extend XTABOND Dynamic Panel Data Estimator," Statistical Software Component S435901 (Boston: Boston College Department of Economics).

Schnure, Calvin, 2005, "Boom-Bust Cycles in Housing: The Changing Role of Financial Structure," IMF Working Paper No. 05/200 (Washington: International Monetary Fund).

Sinai, Todd and Nicholas Souleles, 2005, “Owner-Occupied Housing as a Hedge Against Rent Risk”, Quarterly Journal of Economics, Vol. 120 (2), May, pp. 763-789.

Stiglitz, Joseph, 1990, "Symposium on Bubbles," Journal of Economic Perspectives, 4(2), Spring, pp. 13-18.

StataCorp, 2005, Base Reference Manual Vol. 3 (College Station, TX: Stata Corporation).

— , 2008, STATA Statistical Software: Release 10 (College Station, TX: Stata Corporation).

Sutton, G., 2002, “Explaining Changes in House Prices”, BIS Quarterly Review, September (Basel: Bank for International Settlements).

Terrones, M. and C. Otrok, 2004, “The Global House Price Boom”, IMF World Economic Outlook, September (Washington: International Monetary Fund).

Tsatsaronis, K. and H. Zhu, 2004, "What Drives Housing Price Dynamics: Cross Country Evidence”, BIS Quarterly Review, March (Basel: Bank for International Settlements).

Verbruggen, J., H. Kranendonk, M. van Leuvensteijn and M. Toet, 2005, "Welke factoren bepalen de ontwikkeling van de huizenprijs in Nederland?," CPB Document 81, April.

Wagner, R., 2005, "En model for de danske ejerboligpriser," Okonom-og Erhvervsministeriets arbejdspapir, Vol. 1.

Wooldridge, J. M., 2002, Econometric Analysis of Cross Section and Panel Data, (Cambridge, MA: MIT Press).

World Bank, 2007, World Development Indicators Database (Washington: World Bank Group).

Zhu, Haibin, 2003, "The Importance of Property Markets for Monetary Policy and Financial Stability," in "Real Estate Indicators and Financial Stability", BIS Papers, Vol. 21, pp. 9-29 (Basel: Bank for International Settlements). 
Survey of Studies of Determinants of Housing Prices

\begin{tabular}{|c|c|c|c|c|c|c|}
\hline \multirow{2}{*}{ Study } & \multirow{2}{*}{ Dependent variable } & \multicolumn{3}{|c|}{ Explanatory variables } & \multirow{2}{*}{ Data } & \multirow{2}{*}{ Estimation method } \\
\hline & & Interest rates & Income & Other & & \\
\hline $\begin{array}{l}\text { Abelson and others } \\
(2005)\end{array}$ & Real house prices & $\begin{array}{l}\text { Real interest rate } \\
\text { (elasticity: }-5.4 \text { ) }\end{array}$ & $\begin{array}{l}\text { Real disposable income } \\
\text { (elasticity: 1.7) }\end{array}$ & $\begin{array}{l}\text { Unemployment (elasticity: }-0.2 \text { ), stock } \\
\text { index (elasticity: }-0.1 \text { ) } \\
\text { Inflation rate (elasticity: } 0.8 \text { ) } \\
\text { Housing stock supply (elasticity: }-3.6 \text { ) }\end{array}$ & $\begin{array}{l}\text { Australia 1975Q1- } \\
\text { 2003Q1, quarterly }\end{array}$ & Error Correction Model \\
\hline $\begin{array}{l}\text { Ahearne and others } \\
(2005)\end{array}$ & Real house prices & $\begin{array}{l}\text { Nominal policy rate }(-) \\
\text { real long-term interest } \\
\text { rate }(-)\end{array}$ & Real GDP growth (+) & $\begin{array}{l}\text { Higher money supply growth before } \\
\text { housing peak, lower afterwards. } \\
\text { Fiscal deficits improve before housing } \\
\text { price peak, deteriorate afterwards. } \\
\text { Current account deficits widen at least } 8 \\
\text { quarters before housing price peak } \\
\text { Population growth (+) } \\
\text { Inflation (+) }\end{array}$ & $\begin{array}{l}18 \text { industrial countries, } \\
1970-2004, \text { quarterly }\end{array}$ & Correlation analysis. \\
\hline Annett (2005) & $\begin{array}{l}\text { Real house prices, } \\
\text { difference in logs }\end{array}$ & $\begin{array}{l}\text { Real, long term } \\
\text { (elasticity }-0.02 \text { ) }\end{array}$ & $\begin{array}{l}\text { Real disposable income } \\
(+)\end{array}$ & Real credit $(+)$ & $\begin{array}{l}8 \text { euro-area countries } \\
1970-2003, \text { annual }\end{array}$ & $\begin{array}{l}\text { Fixed effects (LSDV) } \\
\text { OLS. Both for panel } \\
\text { and individual series }\end{array}$ \\
\hline $\begin{array}{l}\text { Almeida, Campbello, } \\
\text { and Liu (2006) }\end{array}$ & $\begin{array}{l}\text { Real prices, difference } \\
\text { in logs }\end{array}$ & $\begin{array}{l}\text { Real, } 10 \text {-yr government } \\
\text { bond rate, deflated by } \\
\text { CPI (elasticity }-0.3 \text { ) }\end{array}$ & $\begin{array}{l}\text { Real per capita GDP, } \\
\text { diff. in logs }(+)\end{array}$ & $\begin{array}{l}\text { Real housing prices to real GDP/capita } \\
(-)\end{array}$ & $\begin{array}{l}26 \text { countries, } 1970- \\
1999, \text { Annual }\end{array}$ & $\begin{array}{l}\text { OLS with lagged } \\
\text { dependent variables } \\
\text { and fixed effects. Also } \\
\text { include Arellano-Bond } \\
\text { dynamic panel GMM. }\end{array}$ \\
\hline $\begin{array}{l}\text { Ayuso and others } \\
(2005)\end{array}$ & Real house prices & $\begin{array}{l}\text { Nominal rate included, } \\
\text { but insignificant }\end{array}$ & $\begin{array}{l}\text { Real disposable income } \\
\text { (elasticity: 2.8) }\end{array}$ & Stock market return $(-0.33)$ & Spain 1978-2002 & Error Correction Model \\
\hline $\begin{array}{l}\text { Bessone and others } \\
(2005)\end{array}$ & $\begin{array}{l}\text { Real house prices } \\
\text { (Paris only) }\end{array}$ & & $\begin{array}{l}\text { Real disposable income } \\
\text { (elasticity: 8.3) }\end{array}$ & Housing stock (elasticity: -3.6) & France 1986-2004 & $\begin{array}{l}\text { Demand and supply } \\
\text { equations, Johansen } \\
\text { ML }\end{array}$ \\
\hline $\begin{array}{l}\text { Collyns and Semlali } \\
(2002)\end{array}$ & $\begin{array}{l}\text { Real, difference in logs; } \\
\text { residential and non- } \\
\text { residential, deflated by } \\
\mathrm{CPI} \text {. }\end{array}$ & $\begin{array}{l}\text { Domestic and foreign } \\
\text { rates included, but } \\
\text { insignificant }\end{array}$ & $\begin{array}{l}\text { Real disposable income } \\
\text { (elasticity: } 0.7-0.9 \text { ) }\end{array}$ & $\begin{array}{l}\text { Real credit }(+) \\
\text { Various dummy variables }\end{array}$ & $\begin{array}{l}\text { East Asian countries, } \\
\text { 1979-2001, quarterly }\end{array}$ & $\begin{array}{l}\text { Panel (OLS, no fixed } \\
\text { effects) Individual } \\
\text { country VARs }\end{array}$ \\
\hline $\begin{array}{l}\text { Fitzpatrick and } \\
\text { McQuinn (2004) }\end{array}$ & & & & $\begin{array}{l}\text { Mortgage credit (elasticity } 1.3 \text { ) } \\
\text { Population } 24-36 \text { (elasticity } 2.0 \text { ) } \\
\text { Housing stock (elasticity }-1.2 \text { ) }\end{array}$ & Ireland, 1981-1999 & $\begin{array}{l}\text { Stock and Watson } \\
\text { DOLS, FM-OLS and } \\
\text { OLS }\end{array}$ \\
\hline Hofman (2005) & Real house prices & $\begin{array}{l}\text { Real interest rate } \\
\text { (elasticity -0.9) }\end{array}$ & $\begin{array}{l}\text { Real disposable income } \\
\text { (elasticity 1.5) }\end{array}$ & & $\begin{array}{l}\text { Netherlands 1974Q1- } \\
\text { 2003Q3, quarterly }\end{array}$ & Error Correction Model \\
\hline Hunt and Badia (2005) & Real house prices & $\begin{array}{l}\text { Real interest rate } \\
\text { (elasticity }-6.0 \text { in 99Q4) }\end{array}$ & $\begin{array}{l}\text { Real disposable income } \\
\text { (elasticity } 1.91 \text { in } \\
1999 Q 4 \text { and } 1.5 \text { in } \\
\text { 2004Q4) }\end{array}$ & & $\begin{array}{l}\text { United Kingdom } \\
\text { 1972Q4-2004Q4, } \\
\text { quarterly }\end{array}$ & Error Correction Model \\
\hline IMF (2008) & Real house prices & $\begin{array}{l}\text { Short-term interest rate } \\
\text { (elast. from } 0 \text { to }-5 \text { ) }\end{array}$ & & $\begin{array}{l}\text { Studies transmission to residential } \\
\text { investment and consumption. }\end{array}$ & $\begin{array}{l}18 \text { advanced } \\
\text { economies, } 1970-2007\end{array}$ & VAR Model \\
\hline $\begin{array}{l}\text { Jacobsen and Naug } \\
\text { (2005) }\end{array}$ & Real house prices & $\begin{array}{l}\text { Real interest rate } \\
\text { (elasticity }-3.2 \text { ) }\end{array}$ & $\begin{array}{l}\text { Real disposable income } \\
\text { (elasticity 1.7) }\end{array}$ & $\begin{array}{l}\text { Housing stock supply (elasticity: }-1.7 \text { ) } \\
\text { Unemployment (elasticity: } 0.5 \text { ) }\end{array}$ & $\begin{array}{l}\text { Norway 1990Q1- } \\
\text { 2004Q1, quarterly }\end{array}$ & Error Correction Model \\
\hline $\begin{array}{l}\text { McCarthy and Peach } \\
(2004)\end{array}$ & Real house prices & & $\begin{array}{l}\text { Real disposable income } \\
\text { (elasticity: } 3.2 \text { ) }\end{array}$ & Housing stock supply (elasticity: -3.2 ) & $\begin{array}{l}\text { United States 1981Q1- } \\
\text { 2003Q3, quarterly }\end{array}$ & $\begin{array}{l}\text { Demand and supply } \\
\text { equations, Johansen } \\
\text { ML estimation }\end{array}$ \\
\hline Meen (2002) & Real house prices & $\begin{array}{l}\text { Real interest rate } \\
\text { (elasticity: }-1.3 \text { ) }\end{array}$ & $\begin{array}{l}\text { Real disposable income } \\
\text { (elasticity: } 2.7 \text { ) }\end{array}$ & $\begin{array}{l}\text { Housing stock supply (elasticity: }-7.9 \text { ) } \\
\text { Also finds that "high growth in prices is } \\
\text { not attributable to weak supply } \\
\text { response." } \\
\text { Real wealth (elasticity=0.7) }\end{array}$ & $\begin{array}{l}\text { United States 1981Q3- } \\
\text { 1998Q2, quarterly }\end{array}$ & Error Correction Model \\
\hline
\end{tabular}




\begin{tabular}{|c|c|c|c|c|c|c|}
\hline \multirow{2}{*}{ Study } & \multirow{2}{*}{ Dependent variable } & \multicolumn{3}{|c|}{ Explanatory variables } & \multirow{2}{*}{ Data } & \multirow{2}{*}{ Estimation method } \\
\hline & & Interest rates & Income & Other & & \\
\hline Meen (2002) & Real house prices & $\begin{array}{l}\text { Real interest rate } \\
\text { (elasticity: }-3.5 \text { ) }\end{array}$ & $\begin{array}{l}\text { Real disposable income } \\
\text { (elasticity: } 2.5 \text { ) }\end{array}$ & Housing stock supply (elasticity: -1.9) & $\begin{array}{l}\text { United Kingdom } \\
\text { 1969Q3-1996Q1, } \\
\text { quarterly }\end{array}$ & Error Correction Model \\
\hline $\begin{array}{l}\text { Muellbauer and Murphy } \\
\text { (1997) }\end{array}$ & $\begin{array}{l}\text { Log of house prices, } \\
\text { deflated by consumer } \\
\text { expenditure deflator }\end{array}$ & & $\begin{array}{l}\text { Real disposable non- } \\
\text { property income }\end{array}$ & $\begin{array}{l}\text { Last housing stock to population (in } \\
\text { logs); Last value of dependent variable. } \\
\text { Proportion of housing stock that is } \\
\text { owner-occupied; Composite assets } \\
\text { Various dummies. }\end{array}$ & United Kingdom & OLS \\
\hline $\begin{array}{l}\text { Nagahata and others } \\
(2004)\end{array}$ & Real house prices & $\begin{array}{l}\text { Real interest rate } \\
\text { (elasticity: }-0.6 \text { to }-4.5 \text { ) }\end{array}$ & $\begin{array}{l}\text { Disposable income } \\
\text { (elasticity: } 0.2 \text { to } 0.5 \text { ) }\end{array}$ & $\begin{array}{l}\text { Price expectations (elasticity } 0.8 \text { to } 0.9 \text { ) } \\
\text { Nonperforming loan ratios have } \\
\text { significant explanatory powers in the } \\
\text { short run. }\end{array}$ & Japan, 1976-2001 & $\begin{array}{l}\text { Panel cointegration } \\
\text { analysis for } 47 \\
\text { prefectures }\end{array}$ \\
\hline $\begin{array}{l}\text { OECD Economic } \\
\text { Survey-Ireland-2005 }\end{array}$ & Real house prices & $\begin{array}{l}\text { Real interest rate } \\
\text { (elasticity: }-1.9 \text { for new } \\
\text { and existing houses) }\end{array}$ & $\begin{array}{l}\text { Disposable income } \\
\text { (elasticity: } 1.8 \text { for new } \\
\text { and existing houses). } \\
\text { Short-run income } \\
\text { elasticities are high in } \\
\text { both equations. }\end{array}$ & $\begin{array}{l}\text { Housing stock/population (elasticity }-2.0 \\
\text { for new houses, }-0.007 \text { for existing } \\
\text { houses) }\end{array}$ & $\begin{array}{l}\text { Ireland, 1977Q1- } \\
\text { 2004Q4 }\end{array}$ & Error Correction Model \\
\hline $\begin{array}{l}\text { OECD Economic } \\
\text { Survey - Netherlands } \\
\text { (2004b) }\end{array}$ & Real house prices & $\begin{array}{l}\text { Real interest rate } \\
\text { (elasticity: }-7.14 \text { ) }\end{array}$ & $\begin{array}{l}\text { Disposable income } \\
\text { (elasticity: 1.94) }\end{array}$ & $\begin{array}{l}\text { Housing stock/population (elasticity: - } \\
0.52 \text { ) }\end{array}$ & $\begin{array}{l}\text { Netherlands, 1970- } \\
2002\end{array}$ & Error Correction Model \\
\hline $\begin{array}{l}\text { OECD Economic } \\
\text { Survey - Spain (2004c) }\end{array}$ & Real house prices & $\begin{array}{l}\text { Real interest rate } \\
\text { (elasticity: }-0.6 \text { to }-4.5 \text { ) }\end{array}$ & $\begin{array}{l}\text { Disposable income } \\
\text { (elasticity: } 3.3 \text { to } 4.1 \text { ) }\end{array}$ & $\begin{array}{l}\text { Population total (elasticity: } 12 \text { to } 16.9 \text { ) } \\
\text { Housing stock/population (elasticity: - } \\
6.9 \text { to }-8.1 \text { ) }\end{array}$ & Spain, 1989-2003 & Error Correction Model \\
\hline Oikarinen (2005) & & $\begin{array}{l}\text { Real interest rate } \\
\text { (elasticity: }-2.2 \text { to }-7.5 \text { ) }\end{array}$ & $\begin{array}{l}\text { Disposable income } \\
\text { (elasticity: } 0.8 \text { to } 1.3 \text { ) }\end{array}$ & & $\begin{array}{l}\text { Finland 1975Q1- } \\
\text { 2005Q2 }\end{array}$ & Error Correction Model \\
\hline Schnure (2005) & Real house prices & $\begin{array}{l}\text { Real interest rate } \\
\text { (short-run elasticity: } \\
-0.21 \text { to }-0.28) \text {. See } \\
\text { also "other" }\end{array}$ & $\begin{array}{l}\text { Real disposable income } \\
\text { (short-run elasticity: } \\
0.21-0.28 \text { ) }\end{array}$ & $\begin{array}{l}\text { Unemployment (elasticity }-0.9 \text { to }-1.2 \text { ), } \\
\text { labor force (short-run elasticity } 0.4 \text { to } \\
\text { 1.8). } \\
\text { Increased sensitivity to interest rates } \\
\text { since } 1990 \text { due to liberalization of } \\
\text { mortgage lending access and higher } \\
\text { securitization. }\end{array}$ & $\begin{array}{l}\text { United States 1978- } \\
2004 \text {, annual }\end{array}$ & $\begin{array}{l}\text { Panel estimation for } \\
\text { regional house prices }\end{array}$ \\
\hline Sutton (2002) & Real house prices & $\begin{array}{l}\text { Short rates }=-0.5 \text { to } \\
-1.5, \text { weaker for long } \\
\text { rates, lowest estimates } \\
\text { for US and UK, highest } \\
\text { for the Netherlands. }\end{array}$ & & $\begin{array}{l}\text { GNP }=1 \text { to } 4 \text { after } 3 \text { years, largest in } \\
\text { Ireland. } \\
\text { Share prices }=1 \text { to } 5 \text { after } 3 \text { years, } \\
\text { largest in the UK }\end{array}$ & $\begin{array}{l}\text { Australia, Canada, } \\
\text { Netherlands, Ireland, } \\
\text { UK, and US, 1970s- } \\
\text { 2002Q1. }\end{array}$ & VAR model \\
\hline $\begin{array}{l}\text { Tsatsaronis and Zhu } \\
(2004)\end{array}$ & Real house prices & $\begin{array}{l}\text { Account for } 11 \% \\
\text { of total variation in } \\
\text { house prices after } 5 \\
\text { years }\end{array}$ & $\begin{array}{l}\text { Real disposable income } \\
\text { accounts for less than } \\
10 \% \text { of total variation in } \\
\text { house prices after } 5 \\
\text { years }\end{array}$ & $\begin{array}{l}\text { Inflation account for } 50 \% \text { of total } \\
\text { variation in house prices after } 5 \text { years, } \\
\text { while bank credit and term spread } \\
\text { account each for around } 10 \%\end{array}$ & $\begin{array}{l}17 \text { countries, grouped } \\
\text { on their mortgage } \\
\text { finance structures, } \\
1970-2003\end{array}$ & VAR model \\
\hline $\begin{array}{l}\text { Terrones and Otrok } \\
(2004)\end{array}$ & Real house prices & $\begin{array}{l}\text { Real interest rate } \\
\text { (elasticity: }-1.0 \text { ) }\end{array}$ & $\begin{array}{l}\text { Real disposable income } \\
\text { (elasticity: 1.1) }\end{array}$ & $\begin{array}{l}\text { Population growth (elasticity } 0.25 \text { ), } \\
\text { housing affordability (elasticity: }-0.14 \text { ), } \\
\text { lagged dependent variable (elasticity: } \\
0.51 \text { ) }\end{array}$ & $\begin{array}{l}18 \text { countries, } 1970- \\
2003\end{array}$ & $\begin{array}{l}\text { Dynamic panel } \\
\text { regressions }\end{array}$ \\
\hline $\begin{array}{l}\text { Verbruggen and others } \\
(2005)\end{array}$ & Real house prices & $\begin{array}{l}\text { Real interest rate } \\
\text { (elasticity: }-5.91 \text { ) }\end{array}$ & $\begin{array}{l}\text { Real disposable income } \\
\text { (elasticity: 1.33) }\end{array}$ & Housing stock supply (elasticity: -1.44 ) & Netherlands $1980-2003$ & Error Correction Model \\
\hline Wagner (2005) & Real house prices & $\begin{array}{l}\text { Real interest rate } \\
\text { (elasticity: }-7.7 \text { ) }\end{array}$ & & $\begin{array}{l}\text { Demographic variables Housing stock } \\
\text { supply (elasticity: }-2.9 \text { ) }\end{array}$ & Denmark & Error Correction Model \\
\hline
\end{tabular}




\section{VARIABLES DEFINITIONS AND DATA SOURCES}

Appendix Table 1. Definitions and Data Sources of Variables

\begin{tabular}{|c|c|c|c|c|c|}
\hline & Variable & Data Series & Unit & Comment & Source \\
\hline \multicolumn{6}{|c|}{ Variables used in Panel Regressions } \\
\hline In_r_housprc & $\begin{array}{l}\text { Real residential property } \\
\text { price index (log) }\end{array}$ & $\begin{array}{l}\text { Index of nominal } \\
\text { residential property } \\
\text { prices (in domestic } \\
\text { currency units) }\end{array}$ & $2000=100$ & Deflated by CPI. & $1,2,3$ \\
\hline In_pcrgdppp & $\begin{array}{l}\text { Real per capita PPP } \\
\text { GDP (log) }\end{array}$ & $\begin{array}{l}\text { Gross Domestic Product, } \\
\text { Volume, } 2000 \text { Constant } \\
\text { PPP }\end{array}$ & $\begin{array}{l}\text { Thousand } \\
2000 \text { PPP } \\
\text { USD }\end{array}$ & & OECD (2008) ${ }^{4}$ \\
\hline srate & Short-term interest rate & Short-term interest rate & Fraction & & OECD (2008) \\
\hline infl & Inflation rate & $\begin{array}{l}\text { Consumer price index } \\
\text { (CPI) }\end{array}$ & $2000=100$ & $\begin{array}{l}\text { Annualized quarter-on- } \\
\text { quarter growth rate. }\end{array}$ & OECD (2008) \\
\hline slpyc & $\begin{array}{l}\text { Slope of yield curve } \\
\text { (difference between long } \\
\text { and short-term rates) }\end{array}$ & $\begin{array}{l}\text { Long-term interest rate } \\
\text { Short-term interest rate }\end{array}$ & Fraction & & $\begin{array}{l}\text { OECD (2008) } \\
\text { OECD (2008) }\end{array}$ \\
\hline unemplr & Unemployment rate & Unemployment rate & Fraction & & OECD (2008) \\
\hline govbal & $\begin{array}{l}\text { Primary government } \\
\text { balance as a ratio to } \\
\text { GDP }\end{array}$ & $\begin{array}{l}\text { Primary government } \\
\text { balance as a percentage } \\
\text { of GDP }\end{array}$ & Fraction & & OECD (2008) \\
\hline curracc & $\begin{array}{l}\text { Current account balance } \\
\text { as a ratio to GDP }\end{array}$ & $\begin{array}{l}\text { Current account balance } \\
\text { as a percentage of GDP }\end{array}$ & Fraction & & OECD (2008) \\
\hline In_r_m2 & $\begin{array}{l}\text { Real broad money (M2) } \\
\text { (log) }\end{array}$ & Broad money & $\begin{array}{l}\text { Billion dom. } \\
\text { currency } \\
\text { units }\end{array}$ & Deflated by CPI. & OECD (2008) \\
\hline \multirow[t]{2}{*}{ shpopa } & $\begin{array}{l}\text { Share of active } \\
\text { population in total }\end{array}$ & $\begin{array}{l}\text { Active population } \\
\text { (aged } 15 \text { to } 64 \text { ) }\end{array}$ & Fraction & & OECD (2008) \\
\hline & population & Total population & & & OECD (2008) \\
\hline \multicolumn{6}{|c|}{ Variables used in Cross-Section Regressions } \\
\hline In_housprcusd & $\begin{array}{l}\text { Residential property } \\
\text { price (log) }\end{array}$ & $\begin{array}{l}\text { Average price per square } \\
\text { meter of an apartment } \\
\text { located in the centre of } \\
\text { the most important city of } \\
\text { each country }\end{array}$ & $\begin{array}{l}\text { US dollars } \\
\text { per square } \\
\text { meter }\end{array}$ & & $\frac{\text { www.globalprope }}{\underline{\text { rtyguide.com }}^{5}}$ \\
\hline In_pcgdpusd & $\begin{array}{l}\text { Per capita nominal GDP } \\
\text { in US dollars (log) }\end{array}$ & $\begin{array}{l}\text { Per capita nominal GDP } \\
\text { in US dollars }\end{array}$ & US dollars & $\begin{array}{l}\text { Average value over } \\
2000-2005\end{array}$ & IMF (2007) \\
\hline infl & Inflation rate & $\begin{array}{l}\text { Consumer price index } \\
\text { (CPI) }\end{array}$ & $2000=100$ & $\begin{array}{l}\text { Average value over } \\
2000-2005\end{array}$ & IMF (2007) \\
\hline srate & $\begin{array}{l}\text { Rate of return on } 91 \text { day } \\
\text { T-bills }\end{array}$ & $\begin{array}{l}\text { Rate of return on } 91 \text { day } \\
\text { T-bills }\end{array}$ & Fraction & $\begin{array}{l}\text { Average value over } \\
2000-2005\end{array}$ & IMF $(2007)^{6}$ \\
\hline$c r d \_g d p$ & $\begin{array}{l}\text { Domestic credit to } \\
\text { private sector in ratio to } \\
\text { GDP }\end{array}$ & $\begin{array}{l}\text { Domestic credit to private } \\
\text { sector in ratio to GDP }\end{array}$ & Fraction & $\begin{array}{l}\text { Average value over } \\
2000-2005\end{array}$ & $\begin{array}{l}\text { World Bank } \\
(2007)\end{array}$ \\
\hline \multirow[t]{2}{*}{ govbal } & $\begin{array}{l}\text { Government balance as } \\
\text { a ratio to GDP }\end{array}$ & $\begin{array}{l}\text { General government } \\
\text { balance }\end{array}$ & $\begin{array}{l}\text { Billion dom. } \\
\text { currency } \\
\text { units }\end{array}$ & $\begin{array}{l}\text { Average value over } \\
2000-2005\end{array}$ & IMF (2007) \\
\hline & & $\begin{array}{l}\text { Gross domestic product, } \\
\text { current prices }\end{array}$ & $\begin{array}{l}\text { Billion dom. } \\
\text { currency } \\
\text { units }\end{array}$ & & \\
\hline unemplr & Unemployment rate & Unemployment rate & Fraction & $\begin{array}{l}\text { Average value over } \\
2000-2005\end{array}$ & IMF (2007) \\
\hline shpopurb & $\begin{array}{l}\text { Percent of urban } \\
\text { population }\end{array}$ & $\begin{array}{l}\text { Urban population in ratio } \\
\text { to total population }\end{array}$ & Fraction & $\begin{array}{l}\text { Average value over } \\
2000-2005\end{array}$ & $\begin{array}{l}\text { UN Population } \\
\text { Division (2007) }\end{array}$ \\
\hline \multirow[t]{2}{*}{ curracc } & $\begin{array}{l}\text { Current account balance } \\
\text { as a ratio to GDP }\end{array}$ & Current account balance & $\begin{array}{l}\text { Billion US } \\
\text { dollars }\end{array}$ & $\begin{array}{l}\text { Average value over } \\
2000-2005\end{array}$ & IMF (2007) \\
\hline & & $\begin{array}{l}\text { Nominal GDP in US } \\
\text { dollars }\end{array}$ & $\begin{array}{l}\text { Billion US } \\
\text { dollars }\end{array}$ & & IMF (2007) \\
\hline
\end{tabular}


Note: The table shows the names of the variables as used to refer to their contemporaneous values. Lags of variables are denoted by suffixes "\#”, where "\#" stands for the number of quarters that separate the referred from the contemporaneous values. First-differences of variables are denoted by the prefix "d1_".

${ }^{1}$ BIS (2005) for historic values prior to the start of published data, national sources data spliced with BIS (2005) data afterwards - Australia: "Price Index of Established Homes (weighted average of 8 capital cities)," Australian Bureau of Statistics; Canada: "New housing price Index," Statistics Canada; Denmark: "Price index for sales of one-family houses," Statistics Denmark; Finland: "Average Price of Detached Houses," Statistics Finland; France: "Ensemble du marché", Fédération Nationale de I'Immobilier; Ireland: "National House Price Index," permanent tsb; Japan: "Urban Land Price Index - Residential, 6 major cities," Japan Real Estate Institute; New Zealand: "All Residential Housing Price Index", Reserve Bank of New Zealand; Norway: "House Price Index, All Dwellings," Statistics Norway; Spain: "Average Price per Square Metre of Open-Market Appraised Housing," Banco de España; Sweden: "Real Estate Price Index for One- and Two-Dwelling Buildings for Permanent Living," Statistics Sweden; Switzerland: "Single-family homes", Swiss National Bank, United Kingdom: "All Houses Index", Nationwide; United States: "House Price Index," Office of the Federal Housing Enterprise Oversight.

${ }^{2}$ BIS (2005) for pre-2005 data (see Arthur, 2005 for details on sources), BIS (2008) data spliced with BIS (2005) data afterwards (under the assumption that all quarter-on-quarter growth rates equal the year-on-year growth rate) - Germany (2005:1-), Italy (2004:1-), and Netherlands (2005:1-).

${ }^{3}$ BIS (2005) for pre-2005 data, EMF (2007) data spliced with BIS (2005) data afterwards_Austria (2003:1-), Belgium (2004:1-), Portugal (2005:1-).

${ }^{4}$ For the 12 Euro area countries, data in monetary units are expressed in euros. For each country, pre-1999 data were converted from national currency using the irrevocable conversion euro rates.

${ }^{5}$ The Global Property Guide publishes data on the average price in US\$ per square meter of upper-end apartments in prestigious areas that appeal to foreign renters in the administrative capital and/or financial capital or the centre of the rental market. For the Caribbean and the Pacific (except for Australia and New Zealand), prices for beachfront properties are reported. Average apartment sizes vary across regions, ranging from 100 to 300 square meters. The data used in the regression analysis is as published on www.globalpropertyguide.com in mid-2007. Data for the scatter plot in Appendix II was updated from the same website in mid-2008.

${ }^{6}$ In case of missing observations, we use data on lending rates from World Bank (2007). 
Appendix Figure 1. Real Residential Housing Price Indices, 1980-2007

(levels of country-specific indices, 2000 $=100$ )

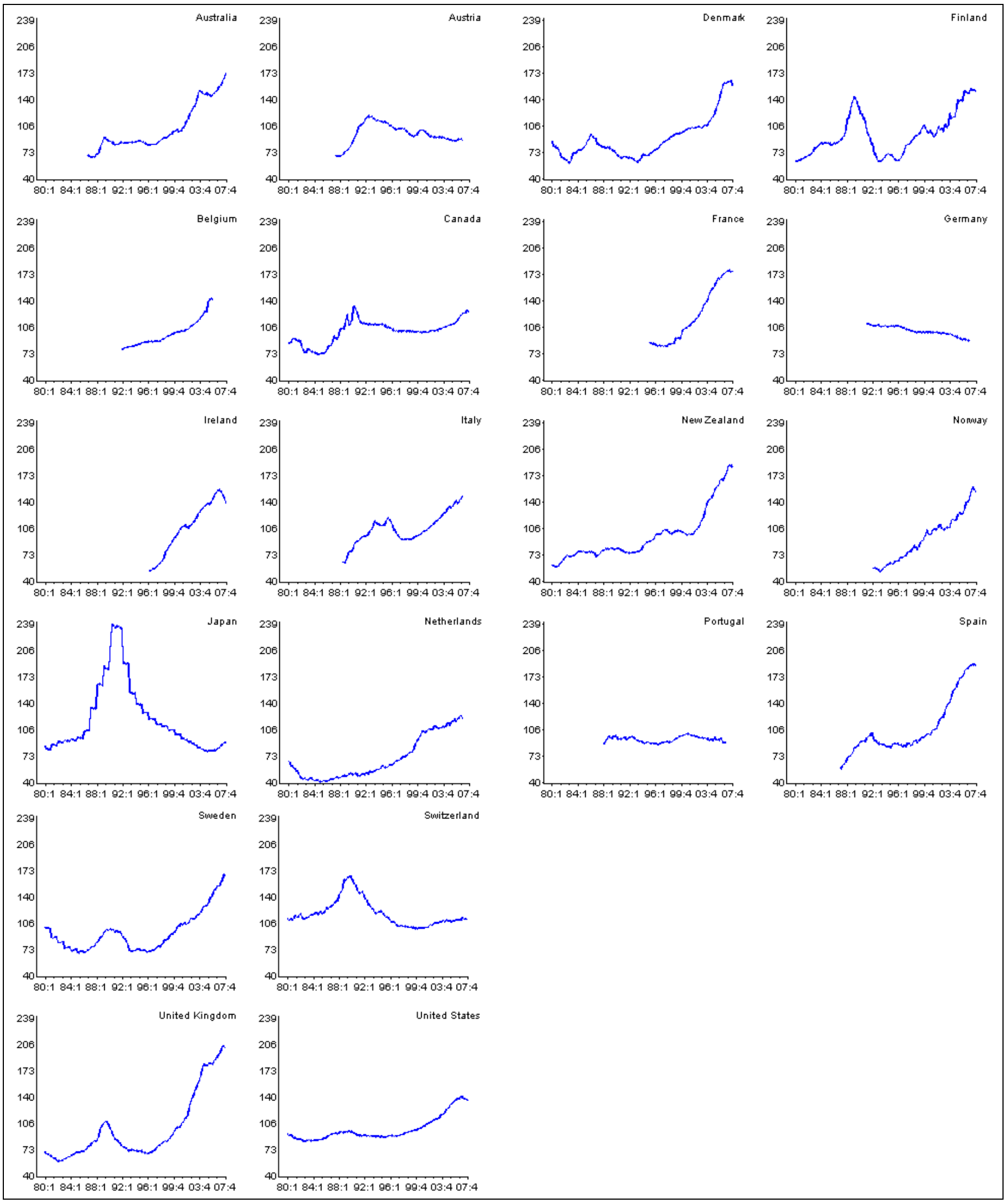

Source: See Appendix Table 1. 
Appendix Figure 2. Scatter Plots of Residential Housing Prices on

Fundamental Determinants Using Cross-Country Dataset
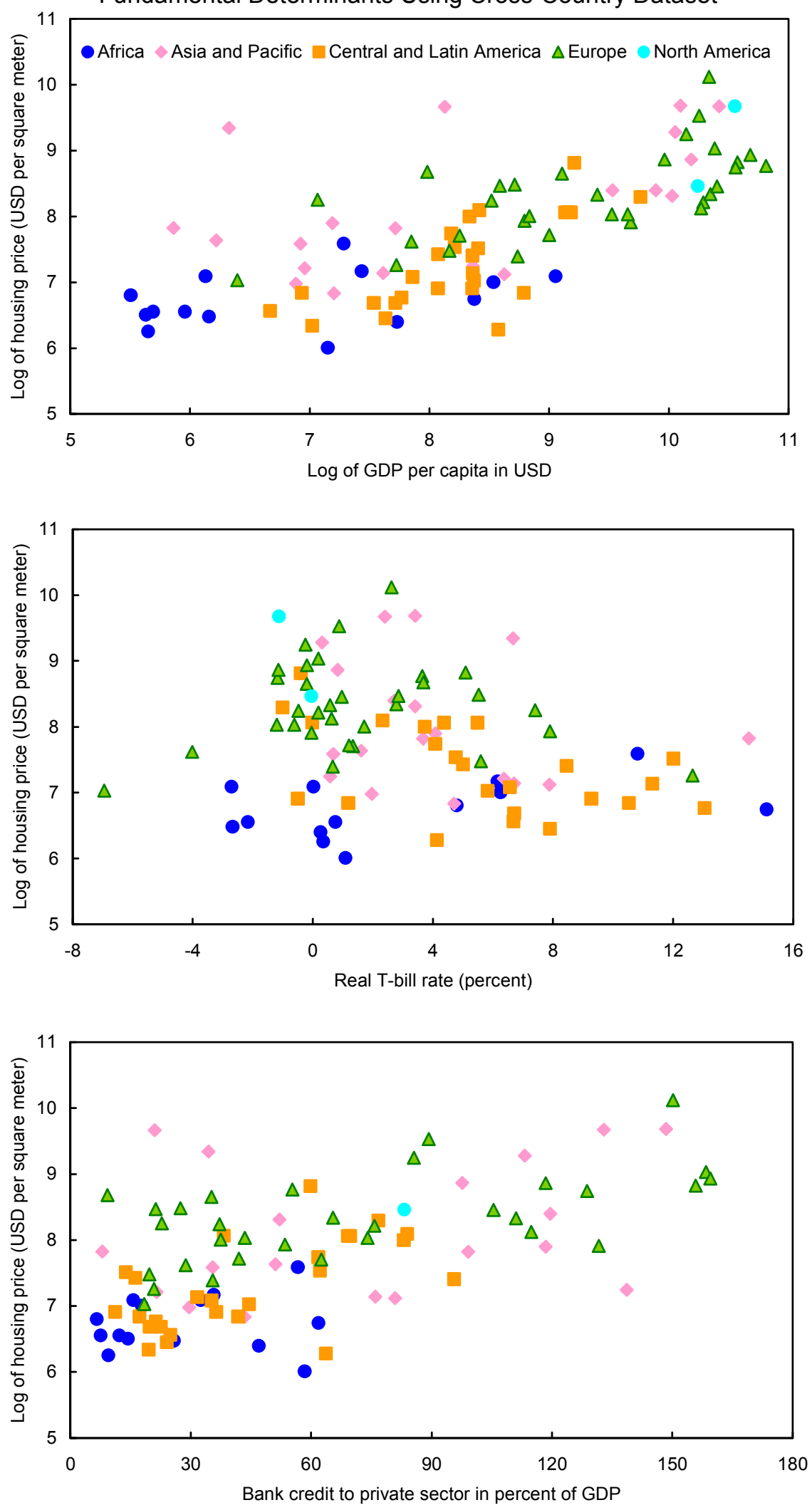

Source: www.globalpropertyguide.com; World Bank's World Development Indicators; and IMF's World Economic Outlook. See also Appendix I. 


\section{ADDitional Regression OUTPUT}

\section{A. Panel Data Regression Analysis}

At the exploratory stage of the analysis we evaluate the different regression models using pooled and within-group (fixed-effects) OLS. ${ }^{22}$ The housing price equation is estimated in semi-loglinear form. The dependent variable is the log of the real residential property price index (ln_r_housprc). Appendix Tables 2 and 3 present the within-group OLS estimates of the different model specifications.

To establish a benchmark model we first enter all variables in contemporaneous levels (Appendix Table 2, Model 1). All demand-side fundamentals except the short-term interest rate, the slope of the yield curve, and the rate of inflation enter significantly in the housing price regression with signs conforming to theoretical priors. The F-test of the joint significance of all fixed effects strongly supports the presence of country-specific fixed effects. The explanatory power of the regression is quite high; however, the Wooldridge test for autocorrelation in panel data (Drukker, 2003) signals the presence of strong residual serial correlation — a sign of a possible "spurious regression" problem.

To clean the housing price equation of the residual serial autocorrelation without imposing a priori restrictions on the dynamic structure of the model, we next estimate a general autoregressive distributed lag model in levels (Appendix Table 3, Model 2), with initial laglength for all variables of six (chosen on the basis of serial correlation tests). The extremely high goodness-of-fit signals a possible overfitting, so we explore reductions of the model.

In Model 3 we drop the second through sixth lags of all explanatory variables except the lagged dependent variable, ${ }^{23}$ balancing the risk of misspecification of the short-run dynamics of the interaction of housing prices with some of the explanatory variables against the benefits of a more parsimonious specification. The coefficients of the contemporaneous level and first-lag of all explanatory variables have opposite signs and in most cases are close in magnitude. This suggests that Model 3 can be more parsimoniously represented by entering all variables except the short-term interest rate in first differences (Model 4).

Model 4 differs from the equilibrium-correction model (ECM), isomorphic to Model 3, by not including the first-lags of the dependent and explanatory variables in levels. We impose these additional restrictions for two reasons: (1) within-group OLS estimation of the ECM representation of Model 3 (not reported) returns a very low value for the equilibriumcorrection coefficient ( 2 percent of the misalignment between actual housing prices and the level consistent with fundamentals is corrected each quarter); and (2) when working with indices, such as the real residential property price index, which bases are not comparable

\footnotetext{
${ }^{22}$ The estimations were performed using STATA (StataCorp, 2008).

${ }^{23}$ The second to sixth lags of each explanatory variable except the lagged dependent one, the rate of inflation, the unemployment rate and the current account balance are jointly statistically insignificant at the 99 percent level of confidence.
} 
between countries, it is arguably more appropriate to pose research questions in terms of contributions of changes in the growth rates of explanatory variables to the rate of growth of the dependent variable rather than in terms of level elasticities. Therefore, the benefits of a more parsimonious specification likely outweigh the potential for misspecification due to the dropping the equilibrium-correction term. In choosing Model 4 over alternative specifications, we concur with the bulk of the literature on housing prices, which estimates the housing price equation in first-differences (Appendix I).

In Model 5 we drop explanatory variables in first-differences that are statistically insignificant at the 95 percent level of confidence (slpyc, curracc, and shpopa). We keep the real per capita PPP GDP due to its importance from a theoretical standpoint. In Model 6, we drop the second through fifth lags of the dependent variable. The reduction is supported by the Wooldridge test for autocorrelation in panel data, which fails to detect serial correlation in excess of the theoretically predicted value of -0.5 at the 95 percent level of confidence.

Model 6 is our preferred interim regression specification of the residential housing price equation in first-differences. All coefficients have signs consistent with theoretical predictions and all except real per capita PPP GDP are statistically significant at the 99 percent level of confidence. The F-test of the joint significance of all fixed effects strongly supports the appropriateness of longitudinal estimation methods by rejecting the hypothesis of a common intercept across countries. The drop in the goodness-of-fit measures of Models 4-6 relative to those of Models 1-3 is due to the first-difference transformation.

The estimation of Model 6 by the GMM-DIF, GMM-SYS, and Anderson and Hsiao instrumental variables (A-H IV) estimators breaks down (Appendix Table 4). In particular, the two-step GMM-DIF and GMM-SYS estimators return markedly different coefficient estimates and larger standard errors than their one-step counterparts, despite the fact that in theory they should be more efficient (Doornik and others, 2002, p. 7). The one-step GMMSYS estimates are very close to their pooled OLS counterparts, signaling a likely overfitting. The reported Sargan tests of overidentifying restrictions are unreliable because of the small cross-sectional unit dimension of the sample, so we cannot draw any conclusions about the validity of the instruments used. The performance of the Anderson and Hsiao instrumental variables (A-H IV) estimators, which are less efficient than the GMM-DIF and GMM-SYS methods, is even worse, with clear biases in coefficient estimates and very large standard errors. 
Appendix Table 2. Within (Fixed Effects) Estimates of the Residential Housing Price Equation

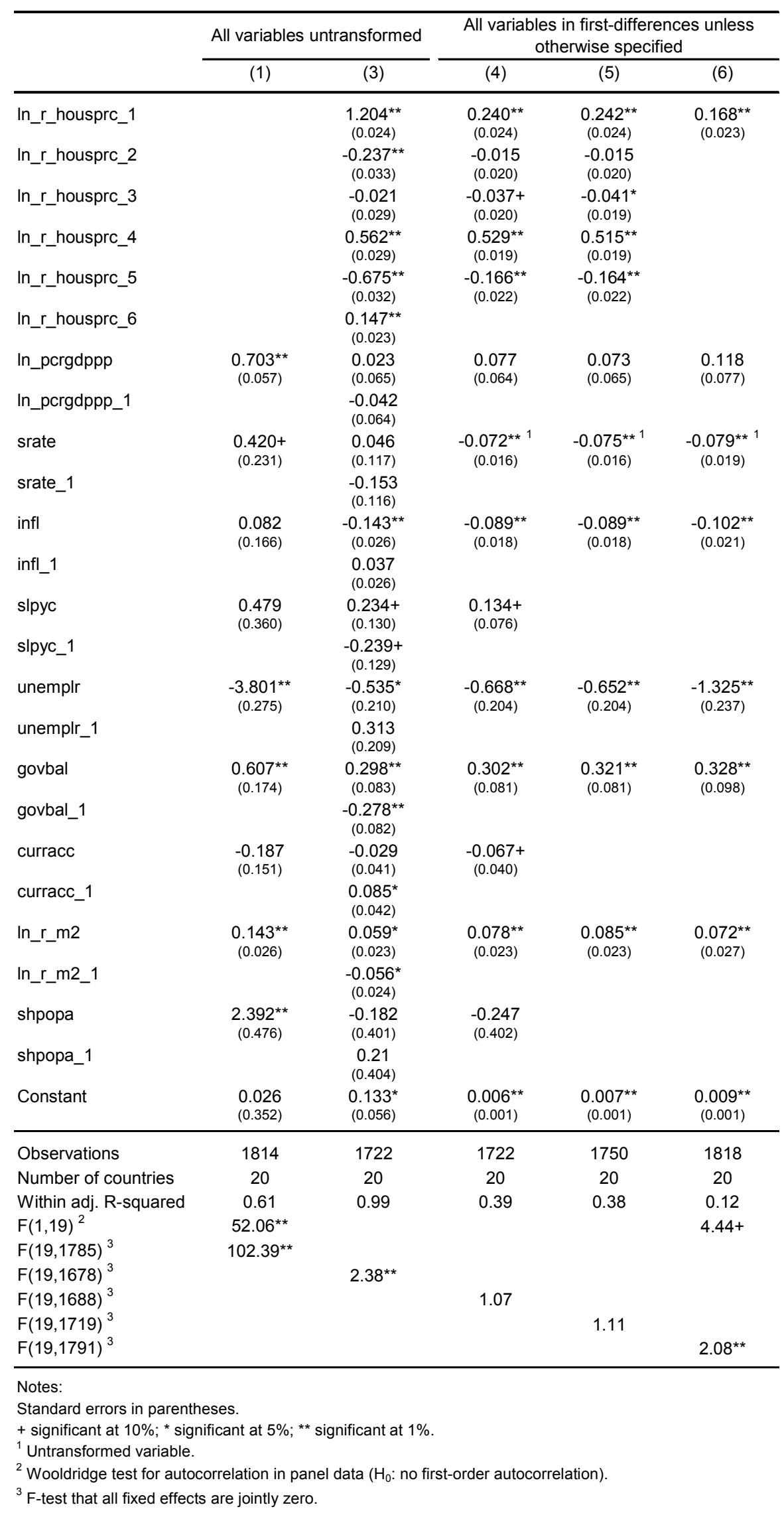


Appendix Table 3. OLS and Within Estimates of Unrestricted Residential Housing Price Equation

\begin{tabular}{|c|c|c|}
\hline & \multicolumn{2}{|c|}{ All variables untransformed } \\
\hline & \multicolumn{2}{|c|}{$(2)$} \\
\hline & OLS & Within \\
\hline In_r_housprc_1 & $\begin{array}{c}1.212^{\star \star} \\
(0.025)\end{array}$ & $\begin{array}{c}1.183^{* *} \\
(0.025)\end{array}$ \\
\hline In_r_housprc_2 & $\begin{array}{c}-0.216^{\star *} \\
(0.034)\end{array}$ & $\begin{array}{c}-0.209^{* *} \\
(0.034)\end{array}$ \\
\hline In_r_housprc_3 & $\begin{array}{r}-0.032 \\
(0.031)\end{array}$ & $\begin{array}{l}-0.031 \\
(0.030)\end{array}$ \\
\hline In_r_housprc_4 & $\begin{array}{c}0.581^{* *} \\
(0.030)\end{array}$ & $\begin{array}{c}0.580^{* *} \\
(0.030)\end{array}$ \\
\hline In_r_housprc_5 & $\begin{array}{c}-0.694^{\star *} \\
(0.033)\end{array}$ & $\begin{array}{c}-0.679^{\star *} \\
(0.033)\end{array}$ \\
\hline In_r_housprc_6 & $\begin{array}{c}0.139^{\star *} \\
(0.024)\end{array}$ & $\begin{array}{c}0.133^{* *} \\
(0.024)\end{array}$ \\
\hline In_pcrgdppp & $\begin{array}{l}-0.009 \\
(0.070)\end{array}$ & $\begin{array}{l}-0.016 \\
(0.071)\end{array}$ \\
\hline In_pcrgdppp_1 & $\begin{array}{l}0.132 \\
(0.091)\end{array}$ & $\begin{array}{l}0.134 \\
(0.091)\end{array}$ \\
\hline In_pcrgdppp_2 & $\begin{array}{l}-0.009 \\
(0.092)\end{array}$ & $\begin{array}{l}-0.005 \\
(0.091)\end{array}$ \\
\hline In_pcrgdppp_3 & $\begin{array}{l}-0.121 \\
(0.090)\end{array}$ & $\begin{array}{l}-0.113 \\
(0.089)\end{array}$ \\
\hline In_pcrgdppp_4 & $\begin{array}{l}0.065 \\
(0.088)\end{array}$ & $\begin{array}{l}0.072 \\
(0.088)\end{array}$ \\
\hline In_pcrgdppp_5 & $\begin{array}{l}-0.033 \\
(0.087)\end{array}$ & $\begin{array}{l}-0.04 \\
(0.087)\end{array}$ \\
\hline In_pcrgdppp_6 & $\begin{array}{l}-0.023 \\
(0.067)\end{array}$ & $\begin{array}{l}-0.052 \\
(0.068)\end{array}$ \\
\hline srate & $\begin{array}{l}0.043 \\
(0.128)\end{array}$ & $\begin{array}{l}0.047 \\
(0.128)\end{array}$ \\
\hline srate_1 & $\begin{array}{l}-0.406^{*} \\
(0.199)\end{array}$ & $\begin{array}{c}-0.407^{*} \\
(0.197)\end{array}$ \\
\hline srate_2 & $\begin{array}{l}0.107 \\
(0.203)\end{array}$ & $\begin{array}{l}0.096 \\
(0.201)\end{array}$ \\
\hline srate_3 & $\begin{array}{l}0.151 \\
(0.201)\end{array}$ & $\begin{array}{l}0.143 \\
(0.200)\end{array}$ \\
\hline srate_4 & $\begin{array}{l}-0.179 \\
(0.201)\end{array}$ & $\begin{array}{l}-0.181 \\
(0.199)\end{array}$ \\
\hline srate_5 & $\begin{array}{l}0.279 \\
(0.193)\end{array}$ & $\begin{array}{l}0.278 \\
(0.192)\end{array}$ \\
\hline srate_6 & $\begin{array}{c}-0.096 \\
(0.121)\end{array}$ & $\begin{array}{l}-0.137 \\
(0.120)\end{array}$ \\
\hline infl & $\begin{array}{c}-0.205^{\star *} \\
(0.032)\end{array}$ & $\begin{array}{c}-0.207^{* *} \\
(0.032)\end{array}$ \\
\hline infl_1 & $\begin{array}{c}0.059+ \\
(0.032)\end{array}$ & $\begin{array}{l}0.051 \\
(0.032)\end{array}$ \\
\hline infl_2 & $\begin{array}{c}0.052+ \\
(0.032)\end{array}$ & $\begin{array}{c}0.05 \\
(0.032)\end{array}$ \\
\hline infl_3 & $\begin{array}{l}0.038 \\
(0.027)\end{array}$ & $\begin{array}{l}0.033 \\
(0.028)\end{array}$ \\
\hline infl_4 & $\begin{array}{c}0.137^{\star *} \\
(0.030)\end{array}$ & $\begin{array}{c}0.134^{\star *} \\
(0.030)\end{array}$ \\
\hline infl_5 & $\begin{array}{l}-0.026 \\
(0.030)\end{array}$ & $\begin{array}{l}-0.028 \\
(0.030)\end{array}$ \\
\hline infl_6 & $\begin{array}{l}-0.034 \\
(0.028)\end{array}$ & $\begin{array}{l}-0.042 \\
(0.028)\end{array}$ \\
\hline slpyc & $\begin{array}{l}0.206 \\
(0.140)\end{array}$ & $\begin{array}{l}0.217 \\
(0.140)\end{array}$ \\
\hline slpyc_1 & $\begin{array}{l}-0.32 \\
(0.214)\end{array}$ & $\begin{array}{l}-0.315 \\
(0.212)\end{array}$ \\
\hline slpyc_2 & $\begin{array}{l}-0.039 \\
(0.218)\end{array}$ & $\begin{array}{l}-0.045 \\
(0.216)\end{array}$ \\
\hline slpyc_3 & $\begin{array}{l}0.235 \\
(0.216)\end{array}$ & $\begin{array}{l}0.226 \\
(0.214)\end{array}$ \\
\hline slpyc_4 & $\begin{array}{l}-0.189 \\
(0.215)\end{array}$ & $\begin{array}{l}-0.182 \\
(0.213)\end{array}$ \\
\hline slpyc_5 & $\begin{array}{l}0.046 \\
(0.209)\end{array}$ & $\begin{array}{l}0.049 \\
(0.207)\end{array}$ \\
\hline slpyc_6 & $\begin{array}{l}0.017 \\
(0.134) \\
\end{array}$ & $\begin{array}{l}0.004 \\
(0.133) \\
\end{array}$ \\
\hline
\end{tabular}


Appendix Table 3. (continued)

\begin{tabular}{|c|c|c|}
\hline & \multicolumn{2}{|c|}{ All variables untransformed } \\
\hline & \multicolumn{2}{|c|}{ (2) } \\
\hline & OLS & Within \\
\hline unemplr & $\begin{array}{c}-0.614^{* *} \\
(0.236)\end{array}$ & $\begin{array}{c}-0.673^{* *} \\
(0.236)\end{array}$ \\
\hline unemplr_1 & $\begin{array}{l}0.388 \\
(0.357)\end{array}$ & $\begin{array}{l}0.366 \\
(0.353)\end{array}$ \\
\hline unemplr_2 & $\begin{array}{l}0.833^{*} \\
(0.358)\end{array}$ & $\begin{array}{l}0.834^{*} \\
(0.354)\end{array}$ \\
\hline unemplr_3 & $\begin{array}{c}-0.596+ \\
(0.358)\end{array}$ & $\begin{array}{l}-0.574 \\
(0.355)\end{array}$ \\
\hline unemplr_4 & $\begin{array}{c}0.03 \\
(0.352)\end{array}$ & $\begin{array}{l}0.056 \\
(0.349)\end{array}$ \\
\hline unemplr_5 & $\begin{array}{l}0.025 \\
(0.352)\end{array}$ & $\begin{array}{l}0.029 \\
(0.349)\end{array}$ \\
\hline unemplr_6 & $\begin{array}{l}-0.071 \\
(0.220)\end{array}$ & $\begin{array}{l}-0.283 \\
(0.223)\end{array}$ \\
\hline govbal & $\begin{array}{c}0.318^{\star *} \\
(0.087)\end{array}$ & $\begin{array}{c}0.300^{* *} \\
(0.087)\end{array}$ \\
\hline govbal_1 & $\begin{array}{l}-0.205 \\
(0.126)\end{array}$ & $\begin{array}{c}-0.206+ \\
(0.125)\end{array}$ \\
\hline govbal_2 & $\begin{array}{l}0.011 \\
(0.126)\end{array}$ & $\begin{array}{l}0.006 \\
(0.125)\end{array}$ \\
\hline govbal_3 & $\begin{array}{l}0.000 \\
(0.125)\end{array}$ & $\begin{array}{l}-0.002 \\
(0.124)\end{array}$ \\
\hline govbal_4 & $\begin{array}{l}-0.131 \\
(0.125)\end{array}$ & $\begin{array}{l}-0.128 \\
(0.124)\end{array}$ \\
\hline govbal_5 & $\begin{array}{l}0.086 \\
(0.125)\end{array}$ & $\begin{array}{l}0.081 \\
(0.124)\end{array}$ \\
\hline govbal_6 & $\begin{array}{l}-0.019 \\
(0.085)\end{array}$ & $\begin{array}{l}-0.033 \\
(0.085)\end{array}$ \\
\hline curracc & $\begin{array}{c}-0.083+ \\
(0.045)\end{array}$ & $\begin{array}{l}-0.058 \\
(0.045)\end{array}$ \\
\hline curracc_1 & $\begin{array}{l}-0.016 \\
(0.051)\end{array}$ & $\begin{array}{l}-0.007 \\
(0.051)\end{array}$ \\
\hline curracc_2 & $\begin{array}{l}0.049 \\
(0.053)\end{array}$ & $\begin{array}{l}0.054 \\
(0.052)\end{array}$ \\
\hline curracc_3 & $\begin{array}{l}-0.068 \\
(0.052)\end{array}$ & $\begin{array}{r}-0.064 \\
(0.052)\end{array}$ \\
\hline curracc_4 & $\begin{array}{l}0.032 \\
(0.052)\end{array}$ & $\begin{array}{l}0.038 \\
(0.052)\end{array}$ \\
\hline curracc_5 & $\begin{array}{l}-0.014 \\
(0.051)\end{array}$ & $\begin{array}{l}0.001 \\
(0.050)\end{array}$ \\
\hline curracc_6 & $\begin{array}{l}0.088^{*} \\
(0.044)\end{array}$ & $\begin{array}{c}0.115^{* *} \\
(0.044)\end{array}$ \\
\hline In_r_m2 & $\begin{array}{l}0.059^{*} \\
(0.025)\end{array}$ & $\begin{array}{l}0.062^{*} \\
(0.025)\end{array}$ \\
\hline In_r_m2_1 & $\begin{array}{l}0.002 \\
(0.035)\end{array}$ & $\begin{array}{l}0.006 \\
(0.034)\end{array}$ \\
\hline In_r_m2_2 & $\begin{array}{l}-0.047 \\
(0.034)\end{array}$ & $\begin{array}{l}-0.046 \\
(0.034)\end{array}$ \\
\hline In_r_m2_3 & $\begin{array}{l}-0.035 \\
(0.033)\end{array}$ & $\begin{array}{l}-0.033 \\
(0.033)\end{array}$ \\
\hline In_r_m2_4 & $\begin{array}{r}-0.017 \\
(0.033)\end{array}$ & $\begin{array}{l}-0.019 \\
(0.033)\end{array}$ \\
\hline In_r_m2_5 & $\begin{array}{l}0.033 \\
(0.034)\end{array}$ & $\begin{array}{l}0.031 \\
(0.033)\end{array}$ \\
\hline In_r_m2_6 & $\begin{array}{l}0.005 \\
(0.024)\end{array}$ & $\begin{array}{l}0.008 \\
(0.024)\end{array}$ \\
\hline shpopa & $\begin{array}{l}0.115 \\
(0.503)\end{array}$ & $\begin{array}{l}0.143 \\
(0.506)\end{array}$ \\
\hline shpopa_1 & $\begin{array}{l}-0.148 \\
(0.739)\end{array}$ & $\begin{array}{r}-0.144 \\
(0.732)\end{array}$ \\
\hline shpopa_2 & $\begin{array}{l}-0.06 \\
(0.645)\end{array}$ & $\begin{array}{l}-0.101 \\
(0.643)\end{array}$ \\
\hline shpopa_3 & $\begin{array}{l}0.414 \\
(0.554)\end{array}$ & $\begin{array}{l}0.388 \\
(0.549)\end{array}$ \\
\hline shpopa_4 & $\begin{array}{l}-0.613 \\
(0.677)\end{array}$ & $\begin{array}{l}-0.581 \\
(0.672)\end{array}$ \\
\hline shpopa_5 & $\begin{array}{l}0.181 \\
(0.799)\end{array}$ & $\begin{array}{l}0.154 \\
(0.792)\end{array}$ \\
\hline shpopa_6 & $\begin{array}{l}0.103 \\
(0.531)\end{array}$ & $\begin{array}{l}0.152 \\
(0.540)\end{array}$ \\
\hline
\end{tabular}


Appendix Table 3. (continued)

\begin{tabular}{|c|c|c|}
\hline & \multicolumn{2}{|c|}{ All variables untransformed } \\
\hline & \multicolumn{2}{|c|}{$(2)$} \\
\hline & OLS & Within \\
\hline Constant & $\begin{array}{c}0.055^{\star *} \\
(0.021)\end{array}$ & $\begin{array}{c}0.138^{*} \\
(0.059)\end{array}$ \\
\hline Observations & 1694 & 1694 \\
\hline Number of countries & 20 & 20 \\
\hline Overall adj. R-squared & 0.99 & \\
\hline Within adj. R-squared & & 0.99 \\
\hline$F(19,1605)^{1}$ & & $2.69^{* *}$ \\
\hline
\end{tabular}

Appendix Table 4. Alternative Estimates of the Residential Housing Price Equation in First-Differences

\begin{tabular}{|c|c|c|c|c|c|c|c|}
\hline & \multirow[t]{2}{*}{ OLS } & \multicolumn{2}{|c|}{ Anderson and Hsiao } & \multicolumn{2}{|c|}{ GMM-DIF } & \multicolumn{2}{|c|}{ GMM-SYS } \\
\hline & & Instruments Differenced & Instruments in Levels & 1-Step & 2-Step & 1-Step & 2-Step \\
\hline & (6) & $(6)$ & $(6)$ & $(6)$ & $(6)$ & $(6)$ & $(6)$ \\
\hline d1_In_r_housprc_1 & $\begin{array}{c}0.193^{* *} \\
(0.023)\end{array}$ & $\begin{array}{c}7.531 \\
(92.635)\end{array}$ & $\begin{array}{c}-0.215 \\
(0.433)\end{array}$ & $\begin{array}{l}0.016 \\
(0.079)\end{array}$ & $\begin{array}{l}-0.23 \\
(0.227)\end{array}$ & $\begin{array}{c}0.193^{*} \\
(0.088)\end{array}$ & $\begin{array}{c}-0.016 \\
(0.367)\end{array}$ \\
\hline d1_In_pcrgdppp & $\begin{array}{c}0.132+ \\
(0.076)\end{array}$ & $\begin{array}{l}-22.436 \\
(427.199)\end{array}$ & $\begin{array}{c}-0.282 \\
(9.104)\end{array}$ & $\begin{array}{l}0.096 \\
(0.072)\end{array}$ & $\begin{array}{l}0.538 \\
(0.772)\end{array}$ & $\begin{array}{l}0.125 \\
(0.076)\end{array}$ & $\begin{array}{l}0.147 \\
(1.014)\end{array}$ \\
\hline srate $^{1}$ & $\begin{array}{c}-0.046^{* *} \\
(0.017)\end{array}$ & $\begin{array}{c}58.863 \\
(1056.941)\end{array}$ & $\begin{array}{l}0.087 \\
(0.875)\end{array}$ & $\begin{array}{c}-0.142^{* *} \\
(0.048)\end{array}$ & $\begin{array}{c}-0.616 \\
(0.454)\end{array}$ & $\begin{array}{c}-0.046+ \\
(0.025)\end{array}$ & $\begin{array}{r}-0.032 \\
(0.344)\end{array}$ \\
\hline d1_infl & $\begin{array}{c}-0.103^{* *} \\
(0.022)\end{array}$ & $\begin{array}{l}-4.542 \\
(75.380)\end{array}$ & $\begin{array}{r}-0.055 \\
(0.201)\end{array}$ & $\begin{array}{c}-0.087^{* *} \\
(0.025)\end{array}$ & $\begin{array}{r}-0.004 \\
(0.090)\end{array}$ & $\begin{array}{c}-0.104^{* *} \\
(0.029)\end{array}$ & $\begin{array}{r}-0.128 \\
(0.144)\end{array}$ \\
\hline d1_unemplr & $\begin{array}{c}-1.450^{* *} \\
(0.237)\end{array}$ & $\begin{array}{l}-181.194 \\
(3355.675)\end{array}$ & $\begin{array}{c}3.853 \\
(23.364)\end{array}$ & $\begin{array}{c}-1.405^{\star *} \\
(0.426)\end{array}$ & $\begin{array}{r}-0.018 \\
(1.344)\end{array}$ & $\begin{array}{c}-1.453^{* *} \\
(0.333)\end{array}$ & $\begin{array}{c}1.59 \\
(2.493)\end{array}$ \\
\hline d1_govbal & $\begin{array}{c}0.317^{* *} \\
(0.098)\end{array}$ & $\begin{array}{l}-218.694 \\
(3945.614)\end{array}$ & $\begin{array}{c}5.823 \\
(24.691)\end{array}$ & $\begin{array}{c}0.336^{*} \\
(0.134)\end{array}$ & $\begin{array}{l}0.931 \\
(0.681)\end{array}$ & $\begin{array}{c}0.316^{*} \\
(0.119)\end{array}$ & $\begin{array}{l}0.371 \\
(1.001)\end{array}$ \\
\hline d1_In_r_m2 & $\begin{array}{c}0.070 * * \\
(0.027)\end{array}$ & $\begin{array}{l}-3.202 \\
(66.738)\end{array}$ & $\begin{array}{l}0.249 \\
(0.964)\end{array}$ & $\begin{array}{l}0.054 \\
(0.041)\end{array}$ & $\begin{array}{l}0.142 \\
(0.201)\end{array}$ & $\begin{array}{c}0.070+ \\
(0.036)\end{array}$ & $\begin{array}{l}0.159 \\
(0.209)\end{array}$ \\
\hline \multirow[t]{2}{*}{ Constant } & $0.007^{* *}$ & & & & & $0.007^{* *}$ & 0.007 \\
\hline & $(0.001)$ & & & & & $(0.002)$ & $(0.018)$ \\
\hline Observations & 1818 & 1746 & 1766 & 1798 & 1798 & 1818 & 1818 \\
\hline Number of ind & 20 & 20 & 20 & 20 & 20 & 20 & 20 \\
\hline Adj. R-squared & 0.12 & & & & & & \\
\hline Chi2(1397) ${ }^{2}$ & & & & $\begin{array}{l}14.32 \\
(1.000)\end{array}$ & $\begin{array}{l}14.32 \\
(1.000)\end{array}$ & & \\
\hline Chi2(1801) ${ }^{2}$ & & & & & & $\begin{array}{c}9.84 \\
(1.000)\end{array}$ & $\begin{array}{c}9.84 \\
(1.000)\end{array}$ \\
\hline
\end{tabular}

Notes:

Robust standard errors, consistent in the presence of any pattern of heteroskedasticity and autocorrelation within panels,

with Windmeijer (2005) finite-sample correction for the two-step covariance matrix, in parentheses.

+ significant at $10 \%$; * significant at $5 \%$; ${ }^{* *}$ significant at $1 \%$.

${ }^{1}$ Untransformed variable.

${ }^{2}$ Sargan test of overidentifying restrictions. $\mathrm{P}$-value in parentheses.

${ }^{3}$ Test of ( $n$-th) order serial correlation in regression residuals, $N(0,1)$.

\section{B. Cross-Section Regression Analysis}

To establish a benchmark model, we sequentially build a multivariate housing price regression by adding demand-side fundamentals one at a time and keeping those with statistically significant coefficients (Appendix Table 5). We further control for time-invariant unobserved heterogeneity and measurement errors, by sequentially adding commonly used control variables, keeping those with statistically significant coefficients. 
Appendix Table 5. OLS Estimates of the Effect of Fundamentals on Residential Housing Prices in Cross-Country Data

\begin{tabular}{|c|c|c|c|c|c|c|c|c|c|c|c|c|c|c|c|}
\hline & (9) & $(10)$ & $(11)$ & $(12)$ & $(13)$ & $(14)$ & $(15)$ & $(16)$ & $(17)$ & $(18)$ & $(19)$ & $(20)$ & $(21)$ & $(22)$ & $(23)$ \\
\hline In_pcgdpusd & $\begin{array}{l}0.487^{\text {** }} \\
(0.044)\end{array}$ & $\begin{array}{l}0.509^{* \star} \\
(0.049)\end{array}$ & $\begin{array}{l}0.465^{* *} \\
(0.049)\end{array}$ & $\begin{array}{l}0.474^{\text {** }} \\
(0.050)\end{array}$ & $\begin{array}{l}0.463^{\text {** }} \\
(0.043)\end{array}$ & $\begin{array}{l}0.387^{\text {** }} \\
(0.057)\end{array}$ & $\begin{array}{l}0.491^{\star *} \\
(0.048)\end{array}$ & $\begin{array}{l}0.488^{* *} \\
(0.045)\end{array}$ & $\begin{array}{l}0.546 \text { ** } \\
(0.058)\end{array}$ & $\begin{array}{l}0.489^{\text {** }} \\
(0.047)\end{array}$ & $\begin{array}{l}0.374^{* *} \\
(0.057)\end{array}$ & $\begin{array}{l}0.275^{* *} \\
(0.070)\end{array}$ & $\begin{array}{l}0.402 \text { ** } \\
(0.104)\end{array}$ & $\begin{array}{l}0.381 \text { ** } \\
(0.071)\end{array}$ & $\begin{array}{l}0.480^{* *} \\
(0.096)\end{array}$ \\
\hline infl & & $\begin{array}{l}0.935 \\
(0.911)\end{array}$ & & $\begin{array}{l}4.966 \text { ** } \\
(1.670)\end{array}$ & & & & & & & & & & & \\
\hline srate & & & $\begin{array}{c}-0.801 \\
(1.002)\end{array}$ & $\begin{array}{c}-4.498 \text { ** } \\
(1.350)\end{array}$ & & & & & & & & & & & \\
\hline r_srate & & & & & $\begin{array}{l}-4.616 \text { ** } \\
(1.396)\end{array}$ & & & & & & $\begin{array}{c}-4.324 \text { ** } \\
(1.566)\end{array}$ & $\begin{array}{c}-3.605 \text { * } \\
(1.803)\end{array}$ & $\begin{array}{c}-4.612^{* *} \\
(1.598)\end{array}$ & $\begin{array}{l}-4.387^{* *} \\
(1.634)\end{array}$ & $\begin{array}{l}-4.395 \text { ** } \\
(1.438)\end{array}$ \\
\hline crd_gdp & & & & & & $\begin{array}{l}0.445^{*} \\
(0.187)\end{array}$ & & & & & $\begin{array}{l}0.398 \text { * } \\
(0.191)\end{array}$ & $\begin{array}{l}0.436 \text { * } \\
(0.207)\end{array}$ & $\begin{array}{l}0.418 \text { * } \\
(0.189)\end{array}$ & $\begin{array}{l}0.327 \\
(0.204)\end{array}$ & $\begin{array}{l}0.477 \text { * } \\
(0.186)\end{array}$ \\
\hline govbal & & & & & & & $\begin{array}{r}-0.435 \\
(2.156)\end{array}$ & & & & & & & & \\
\hline unemplr & & & & & & & & $\begin{array}{r}0.06 \\
(0.615)\end{array}$ & & & & & & & \\
\hline shpopurb & & & & & & & & & $\begin{array}{r}-0.585 \\
(0.444)\end{array}$ & & & & & & \\
\hline curracc & & & & & & & & & & $\begin{array}{r}-0.095 \\
(0.815)\end{array}$ & & & & & \\
\hline \multicolumn{16}{|l|}{ Regional dummy variables } \\
\hline Asia and Pacific & & & & & & & & & & & & $\begin{array}{r}-0.158 \\
(0.218)\end{array}$ & & & \\
\hline North America & & & & & & & & & & & & $\begin{array}{r}-0.134 \\
(0.351)\end{array}$ & & & \\
\hline Central and Latin America & & & & & & & & & & & & $\begin{array}{c}-0.369+ \\
(0.193)\end{array}$ & & & \\
\hline Africa & & & & & & & & & & & & $\begin{array}{l}-0.627^{* *} \\
(0.195)\end{array}$ & & & \\
\hline \multicolumn{16}{|l|}{ Institutions } \\
\hline Governance rank & & & & & & & & & & & & & $\begin{array}{l}0.001 \\
(0.003)\end{array}$ & & \\
\hline Business rank & & & & & & & & & & & & & & $\begin{array}{l}0.000 \\
(0.002)\end{array}$ & \\
\hline Corruption rank & & & & & & & & & & & & & & & $\begin{array}{l}0.004 \\
(0.003)\end{array}$ \\
\hline Intercept & $\begin{array}{l}3.545^{* *} \\
(0.376)\end{array}$ & $\begin{array}{l}3.299^{* *} \\
(0.442)\end{array}$ & $\begin{array}{l}3.816^{* *} \\
(0.472)\end{array}$ & $\begin{array}{l}3.762 \text { ** } \\
(0.440)\end{array}$ & $\begin{array}{l}3.894 \text { ** } \\
(0.377)\end{array}$ & $\begin{array}{l}4.126 \text { ** } \\
(0.411)\end{array}$ & $\begin{array}{l}3.505^{* *} \\
(0.431)\end{array}$ & $\begin{array}{l}3.533^{* *} \\
(0.398)\end{array}$ & $\begin{array}{l}3.409 \text { ** } \\
(0.391)\end{array}$ & $\begin{array}{l}3.531 \text { ** } \\
(0.411)\end{array}$ & $\begin{array}{l}4.392 \text { ** } \\
(0.415)\end{array}$ & $\begin{array}{l}5.425^{* *} \\
(0.578)\end{array}$ & $\begin{array}{l}4.064 \text { ** } \\
(1.048)\end{array}$ & $\begin{array}{l}4.395^{* *} \\
(0.671)\end{array}$ & $\begin{array}{l}3.141^{\text {** }} \\
(0.962)\end{array}$ \\
\hline Number of countries & 89 & 89 & 89 & 89 & 89 & 89 & 89 & 88 & 87 & 89 & 89 & 89 & 88 & 82 & 88 \\
\hline Overall $R^{2}$ & 0.52 & 0.53 & 0.53 & 0.57 & 0.57 & 0.55 & 0.52 & 0.52 & 0.53 & 0.52 & 0.59 & 0.63 & 0.60 & 0.61 & 0.61 \\
\hline
\end{tabular}

Note: Robust standard errors consistent in the presence of heteroskedasticity.

+ significant at $10 \%$; ${ }^{*}$ significant at $5 \%$; ${ }^{* *}$ significant at $1 \%$. 